\title{
Electrodialysis with bipolar membranes for valorization of brines
}

\author{
Carolina Fernandez-Gonzalez*, Antonio Dominguez-Ramos, Raquel Ibañez, Angel Irabien \\ Departamento de Ingenierías Química y Biomolecular, ETS Ingenieros Industriales y de \\ Telecomunicación, Universidad de Cantabria, Avda. Los Castros, s.n., Santander, 39005, Spain \\ *Corresponding author: fernandezgoc@unican.es, telephone: +34 942206778
}

Received on Aug. 7, 2015; revised on Oct. 23, 2015; accepted on Nov. 24, 2015

Short running title: Electrodialysis for brine valorization

Keywords: Electrodialysis, brines, valorization, membranes, reverse osmosis.

Abstract

Several industrial processes, such as desalination or neutralization, generate brines defined as concentrated solutions of salts in water, usually $\mathrm{NaCl}$, typically discharged in the vicinities of the desalination plant or factory. In order to reduce the environmental impact and promote the valorization of the wasted resources, alternatives must be sought. Among sustainable alternatives for the recovery of brines, the possibility of using Electrodialysis with Bipolar Membranes (EDBM) is of interest since it allows recovering brines as useful acids and bases. This review focuses on the discussion of the technical aspects of the EDBM as a mean to treat streams rich in $\mathrm{NaCl}$ from reverse osmosis desalination and industrial processes in order to complete the direct delivery of chemicals for self-supply. The main environmental issues associated with desalination brine disposal are presented. The state-of-the-art of valorization of brines by EDBM to acids and bases is completed. This work concludes with an in-depth 
discussion of the technical, techno-economic and economic barriers that prevent the widespread use of EDBM technology.

\section{Introduction}

Large volumes of brines, which are concentrated aqueous solutions of salts, are generated by different industrial processes, which can be grouped into desalination and other manufacturing sectors non-related to fresh water production.

The desalination industry is one of the most important industries in terms of brine generation. Since sea water is used, sodium chloride $(\mathrm{NaCl})$ is the highly concentrated salt in the waste stream composition. The world global desalination capacity in 2010 was around 62.5 million $\mathrm{m}^{3}$ per day (1). However conventional desalination technologies, such as Reverse Osmosis (RO) and Electrodialysis (ED) operate with a recovery interval between $50 \%$ and $80 \%$ (2). They generate high amounts of brines whose typical compositions can be found elsewhere (3). The most common methods for the disposal of brines generated in desalination are evaporation ponds (4), discharge into abandened mines or deep wells (5), coastal discharge (6), concentrate mixing (7) and sewer disposal (8). Nonetheless, while a great amount of disposal methods for brines are available, all of them present several limitations related to environmental issues such as the need of large amounts of land for evaporation ponds $(9,10)$, risk of salt leakages to groundwater (1012) and modification of physicochemical characteristics of the receiving media (12-14). Indeed, the modification of those very receiving environments and its potential impact upon marine communities is the main concern of brine disposal (15). On the other hand, the disposal of such 
a large quantity of hyper-saline brines is a problem for inland high capacity desalination plants that cannot dispose the brine into an inland body of water. The disposal of brines is such a critical issue for inland desalination plants that it sometimes compromises the economy of the desalination process and the viability of the construction of a desalination plant. In this sense, the sustainability of the production of fresh water by means of desalination is compromised as long as it has negative direct consequences from the release of brines to the aquatic environment and indirect from the utilization of electricity.

However, the desalination industry is not the only activity producing brines that should be treated before disposal. Other manufacturing sectors, non-related to water production such as the textile industry (16), generate important amounts of wastewaters with high salt contents. Those salts should be removed before the disposal to sewage systems.

The need for efficient water and wastewater treatments, including recovery of resources, has become a priority in the development of sustainable processes for the efficient recovery and valorization of brines. This should, lead to the development of new or improved innovative water treatment solutions in a real environment. On the other hand, it contributes to reduce the environmental impact of many current industries but at the same time, it promotes an increased volume of recovered water.

Alternative treatments for desalination brines have been extensively reviewed in the literature (17-22). Many innovative studies are focusing on the efficient water and wastewater treatment including recovery of resources contained in the discharged brines. 
Electrodialysis with bipolar membranes (EDBM) is an emerging technology for treatment and valorization of desalination brines that generates acids and bases, chemicals of great interest in any desalination plants. Additionally, EDBM is also a promising alternative for the treatment and valorization of industrial wastewaters of very different nature: metal processing (23), production of rubber (24), wood processing (25), beverage industry (26) and production of acetaldehyde (27). Nevertheless, the present review focuses mainly on the industrial wastewaters with high $\mathrm{NaCl}$ content. These brines are similar to desalination brines in both nature and obtained products: $\mathrm{HCl}$ and $\mathrm{NaOH}$. This facilitates the in-depth techno-economic analysis of the products $\mathrm{HCl}$ and $\mathrm{NaOH}$ by EDBM, no matter the source of the brine.

The use of $\mathrm{HCl}$ in a desalination plant is a good example of the potential use of the EDBM products obtained in the treatment of brines. The conventional pretreatment steps in a desalination plant equipped with $\mathrm{RO}$ are related to $\mathrm{pH}$ control in order to avoid scaling (28) occurring at neutral $\mathrm{pH}$ (29). This $\mathrm{pH}$ adjustment requires noticeable quantities of acid solutions (even $\mathrm{H}_{2} \mathrm{SO}_{4}$ ) depending on the concentration of $\mathrm{CaCO}_{3}$ in the feed stream (30). A range of dosage from 15 to $97 \mathrm{mg} \cdot \mathrm{L}^{-1}$ of $\mathrm{H}_{2} \mathrm{SO}_{4}$ has been reported for commercial RO plants (29). According to (31), $16.4 \mathrm{mg} \cdot \mathrm{L}^{-1}$ of $\mathrm{H}_{2} \mathrm{SO}_{4}$ were needed to add in the stream of a plant with a capacity of $7,000 \mathrm{~m}^{3} \cdot \mathrm{d}^{-1}$, making an equivalent acid of $115 \mathrm{~kg}$ per day. To illustrate this point, the desalination plant described in (12) was reported to require 9.4 tons per day of $\mathrm{H}_{2} \mathrm{SO}_{4}$ considering its capacity of $312,000 \mathrm{~m}^{3} \cdot \mathrm{d}^{-1}$ and a dosage of $30 \mathrm{mg} \cdot \mathrm{L}^{-1}$ of $\mathrm{H}_{2} \mathrm{SO}_{4}$ (98\% wt.). Consequently, it makes sense to consider that a RO desalination plant requires a total dosage of $15-100 \mathrm{mg} \cdot \mathrm{L}^{-1}$ of $\mathrm{H}_{2} \mathrm{SO}_{4}$ that may be replaced by $11-73 \mathrm{mg} \cdot \mathrm{L}^{-1}$ of $\mathrm{HCl}$, highlighting the potential benefit of the in-situ generation of acids by treating desalination brines by EDBM. 
Additionally, the transport and storage of these acids are avoided. This suppresses safety risks when the acid production facilities are far away from the desalination plants (32).

The purchase of these reagents, together with other chemicals used in the pre-treatment and posttreatment of desalination plants (flocculants, scale inhibitors, biocides, etc. (33)), might have a significant contribution to the operation costs of seawater desalination (6\% (34), 4-7 \% (35) and $9 \%$ (36)). According to (37), the contribution of the purchase of all chemicals could make up to $78 \%$ of the process cost. Consequently, the potential benefits in economic terms of brine treatment and valorization must be analyzed. Indeed, the cost of disposal to surface water is around US\$ 0.03 and 0.3 per cubic meter $\left(0.02-0.02 € \cdot \mathrm{m}^{-3}\right)(11)$. It is still much lower than other conventional disposal options $\left(0.3-10.04 \$ \cdot \mathrm{m}^{-3}, 0.2-7.5 € \cdot \mathrm{m}^{-3}\right)$ and even less than emerging brine treatments $\left(0.66-26.4 \$ \cdot \mathrm{m}^{-3}, 0.49-19.6 € \cdot \mathrm{m}^{-3}\right)(11)$. On the other hand, interesting future options to add revenues to the current cost of water are the advanced recovery processes such as selective precipitation or membrane crystallization. Thus the sodium and the chloride, as well as the minor metals causing environmental problems later described, are avoided and valorized as products.

EDBM can be integrated with RO when the retentate can be 1.3 to 1.7 times more concentrated than the original seawater (12). This integration allows for brine valorization making possible the self-supply of acids and bases for several utility purposes such as cleaning of membranes. The benefits in terms of environmental sustainability are then clear because of the diminished need of external chemicals. 
Consequently, the application of EDBM for brine treatment can be potentially cost-effective when the purchase of chemical (making between 6 and78 \% of operation cost) is avoided. Also the disposal costs are partially diminished and the integration of advanced recovery processes may be the source of new incomes.

In order to put EDBM in operation, an in-depth analysis of the techno-economic barriers that prevent this technology to be fully implemented for brine and wastewater valorization should be done. Hence, the aim of this work is the update of the state-of-the-art of EDBM valorization as a source of acids and bases, making special emphasis on challenges. A summary of the main environmental concerns about disposal of desalination brines has also been included.

As a result, this review focuses on the three following aspects: i) environmental issues related to desalination brine disposal; ii) state-of-the-art of EDBM for the production of $\mathrm{HCl}$ and $\mathrm{NaOH}$ from desalination brines and industrial salted wastewaters; and iii) summary of the current technical and economic barriers that prevent a larger market penetration of EDBM for this specific application.

\section{Environmental issues of desalination brines}

In the past, environmental problems caused by brine disposal used to be ignored (38). Now, new approaches require special measures before any brines can be discharged. These measures include the removal of chemicals (e.g. de-chlorination) in order to reduce environmental impact (39). The environmental research about the impact of desalination focused on the effect of brines on the physicochemical characteristics of the receiving media, principally temperature, 
salinity and introduction of contaminants. The contamination of underground aquifers and freshwater sources is a serious concern in the case of inland desalination plants. Regarding to coastal discharge, the main concern is the effect of these modifications in the marine wild life near the outfall and the potential irreparable damage to the marine environment (15). Consequences of brine disposal upon the salinity of the media are the most studied physicochemical modifications.

Regarding to the extent of the alteration, it is reported that the spreading of the salinity plume can range from tens of meters to several kilometers, but in most cases a rapid dilution of the plume takes place with a maximum increase of $2.0 \mathrm{mg} \cdot \mathrm{L}^{-1}$ in salinity media (13). Because of their high salinity, brines are denser than seawater and remain on the seabed (40). As marine organisms live in osmotic balance with their environment, changes in the salinity of the media may cause dehydration of the cells, decrease in the turgor pressure and even death in the case of larvae and young specimens (12). Additionally, the high salinity may lead to an increase of turbidity, which disrupts the photosynthesis process and the biogenesis, affecting larvae and young individual of benthic communities (41). The reported impact was found to be variable from no significant impacts on benthic communities to wide spread alteration to community structures in seagrass, coral reef and soft sediment ecosystems when discharges occurs in poorly flushed environments (13). So, well flushed areas and sandy bottoms without vegetation are the best disposal points recommended in order to minimize damages $(42,43)$. A concentration threshold has been established in order to protect Posidonia oceanica (43). However, the sensitivity related to salinity varies among species (12) and it is not possible to provide a global salinity value capable of protect the seagrass communities (13). Additionally, even though the majority of organisms 
can adapt to minor deviations from optimal salinity and temperature conditions, they cannot stand a continuous exposure to adverse conditions (28). To date and with the published data, the salinity level at which organisms can tolerate long-term exposures cannot be established (44).

Regarding the effect of temperature, the discharges of thermal desalination plants are usually between $8-15{ }^{\circ} \mathrm{C}$ above ambient temperature of seawater (41). The reported effect of these warm discharges varied from modifications in the media of $0.1-0.5{ }^{\circ} \mathrm{C}$ in $7 \mathrm{~km}^{2}$ surrounding the outfall to a minimum impact in the vicinity of the outfall (13). A change in the temperature of water affects numerous properties such as the amount of dissolved oxygen, solubility, viscosity, density, surface stress and nitrogen solubility (41). However, no definitive conclusion can be found about the specific impact of a temperature increase on marine communities.

With respect to the introduction of chemicals in the environment, the type of contaminant that can be found in the surroundings of a desalination plant depends on its cleaning and pretreatment requirements. While both thermal and membrane process require treatment against biofouling and scaling, thermal plants need specific treatment to combat foaming and corrosion whereas membrane processes need careful elimination of suspended solids (28). The most common measure against biofouling is the addition of chlorine in the intake water. Chlorine is a toxic compound that in the marine media can form harmful byproducts such as halogenated organic compounds and chlorites $(14,28)$. The anti-scalants added in desalination plants, mainly polycarbonic acids and phosphonates, have a very low toxicity to the aquatic life but are associated with eutrophication and present a low biodegradability (28). Corrosion problems are responsible for the release of heavy metal contaminants in desalination brines. High 
concentrations of copper, attributable to corrosion in heat exchangers, are usually found in thermal brines. In the case of $\mathrm{RO}$ plants, traces of $\mathrm{Fe}, \mathrm{Ni}, \mathrm{Cr}$ and $\mathrm{Mo}$ can be recorded (28). The accumulation of heavy metals may take place in the sediments and the surroundings of the desalination plant causing damage to the marine communities. In fact, the disposal of brines with high content in $\mathrm{Cu}$ was recognized to be the cause of the reduction of plankton, sessile invertebrates and echinoderms (13).

Due to increasing environmental concerns and the deleterious impact of brines on the environment, the introduction of environmental tools in the early design stage of desalination plants was proposed (45). Environmental impact assessment (EIA) is recommended in order to evaluate the potential impacts of desalination plant discharges and for its best localization selection (10). EIA has already been applied in the creation of desalination plants in Taiwan, USA, Australia, Israel and Japan (15). The methodology should comprehend the plant layout, plant emissions, environmental implications, energy consideration, benefits, evaluation of the impact upon the environment and proposal of mitigation measures (46). In Europe, desalination plants, as any other public and private projects, should be approved under the Impact Assessment Directive (85/337CEE) later codified as Directive 2011/92/EU (47) and amended in 2014 by Directive 2014/52/EU. Other tools such as life cycle assessment were also proposed in water planning in order to achieve a sustainable water supply $(48,49)$. 


\section{The state-of-the-art of electrodialysis for acids and}

\section{bases production from brines}

Electrodialysis with bipolar membranes (EDBM) is a variation of ED in which bipolar membranes (BM) are used. In both cases, an electric field is applied as the driving force for the separation of ions through ion exchange membranes. However, while ED uses only cation exchange membranes, anion exchanges membranes, and electrodes, EDBM uses bipolar membranes as the core of the technology. These membranes are composed by at least two different layers, a cation selective layer and an anion selective layer allowing the splitting of water into protons and hydroxyl ions and the consequent selective transport of the products of water dissociation $(50,51)$. Both ED and EDBM technologies request energy under relatively high-efficiency energy consumption figures (50). Their potential for coupling with renewable energies for freshwater supply was recently reviewed in order to promote alternative sustainable freshwater desalination (52). In depth descriptions of electrodialysis and bipolar membranes can be found in (53) and (54) respectively. Figure 1 shows a possible configuration of the EDBM stack used in order to produce acids and bases from desalination brines.

There are several inorganic sodium salts such as $\mathrm{Na}_{2} \mathrm{CO}_{3}, \mathrm{NaNO}_{3}, \mathrm{Na}_{2} \mathrm{SO}_{4}, \mathrm{Na}_{3} \mathrm{PO}_{4}$ and $\mathrm{NaCl}$ that are reported to generate acids and bases by EDBM, with $\mathrm{NaCl}$ as the main pursued salt (55). Several publications reported the use of EDBM for the generation of $\mathrm{HCl}$ and $\mathrm{NaOH}$ from desalination brines and industrial wastewaters (56-66). Some of the treated salty streams were 
desalination retentates from $\mathrm{RO}$ plants producing drinking water $(56,57)$ or industrial wastewaters with a high content of $\mathrm{NaCl}(58-66)$.

In (58), EDBM is used to treat concentrates from RO, ED with reversal polarity and ion exchange (IEx) in a desalination plant of surface water. Acids and bases were obtained with a concentration between $1 \mathrm{M}$ and $1.5 \mathrm{M}$. It was pointed out that the obtained products were suitable for some treatment stages of the desalination plant such as regeneration of ion exchangers, neutralization of the EDBM feed and alkaline precipitation. In this study, conventional IEx, conventional RO, and the combination of RO and EDBM processes were compared in terms of chemical demand, feed water amount, energy consumption and wastewater generation for the same production of freshwater. The EDBM alternative was reported to need less feed water, produce less wastewater and consume fewer chemicals. However, in this particular study, the EDBM energy demand was higher than that in the case of conventional desalination processes.

In the same line, the combination of IEx (desalination and partial hardness removal of brines), ED (concentration of the brine and partial hardness removal) and EDBM was proposed for the simultaneous production of industrial water, acids and bases from surface water (59). The obtained acids were used in the regeneration of IEx resins. A significant reduction in current efficiency was observed when increasing product concentration. The concentration of the obtained acids was set to $0.9 \mathrm{M}$ only, enough for the regeneration of IEx resins and allowing for a relatively high current efficiency (around $47 \%$ ). The feasibility of producing acids and bases from a wastewater-RO retentate was described (56). The products were obtained with a $0.2 \mathrm{~N}$ 
concentration and their qualities were compared to a technical grade and a national formulary grade. The presence of heavy metals was similar to the chosen standards but a higher concentration of chloride in the produced base was reported when compared to the mentioned national formulary grade. Additionally, a preliminary economic assessment was carried out and four different types of brine treatments were compared: evaporation ponds, softening plus EDBM, electrochlorination and concentration plus crystallization. The economic analysis pointed that the option involving EDBM had the lowest investment cost. The operational cost was also the lowest, estimated in 0.35 US $\$ \cdot \mathrm{m}^{-3}\left(0.26 € \cdot \mathrm{m}^{-3}\right)$. Additionally, using the EDBM treatment train, an additional 0.1 US $\$ \cdot \mathrm{m}^{-3}\left(0.075 € \cdot \mathrm{m}^{-3}\right)$ can be recovered due to the sale of acids, bases and freshwater. Reference (65) proposes the in-situ generation of $\mathrm{HCl}$ and $\mathrm{NaOH}$ for ion exchange regeneration as an alternative to the purchase of acids and bases. $\mathrm{HCl}$ and $\mathrm{NaOH} 0.3 \mathrm{M}$ were produced from diluted salt solutions. A preliminary cost comparison for purchasing bulk $\mathrm{HCl}$ and $\mathrm{NaOH}$ and the in-situ generation of the acid and the base showed a significant reduction of cost from $37 \$ \cdot \mathrm{kmol}^{-1}$ to $3.5-12.6 \$ \cdot \mathrm{kmol}^{-1}$ for $\mathrm{HCl}$ and from $21 \$$. $\mathrm{kmol}^{-1}$ to $3.5-12.6 \$ \cdot \mathrm{kmol}^{-1}$ for the base.

In a recent study (57) the authors used synthetic softened solutions with a composition equivalent to the brine of a RO treatment plant fed by brackish water. The maximum concentration obtained was $0.8 \mathrm{M}$ for the acid and $1 \mathrm{M}$ for the base. The quality of the products was compared to commercial grade from a facility located in Torrelavega, Spain (Solvay Química). The presence of impurities prevented the products to reach the commercial grade. However, these acids and bases could be used in routine operations not needing pure chemicals such as washing stages or $\mathrm{pH}$ control. The treatment of actual brines from a desalination plant fed by seawater 
using EDBM was also described (32). The maximum acid concentration was $1.2 \mathrm{M}$ and the authors reported the technical feasibility of the EDBM set-up to produce $1 \mathrm{M}$ of mixed acids in a continuous mode. Specific energy consumptions of 7.5-8.3 $\mathrm{kWh} \cdot \mathrm{kg}^{-1} \mathrm{HCl}$ with faradic current efficiencies in the range of 52-74\% were reported for current densities belonging to the range 340-570 A $\cdot \mathrm{m}^{-2}$. Here again, the qualities of the obtained acid and base did not achieve industrial or higher requirements, thus additional purification stages must be applied if necessary. The obtained $\mathrm{HCl}$ was efficient in local pretreatment operations. The treatment of a glyphosate neutralization liquor for a zero liquid discharge approach with simultaneous recovery of glyphosate and production of $\mathrm{HCl}$ and $\mathrm{NaOH}$ was described $(60,61)$ The two products were used in the recovery of the catalyst in the manufacturing process of glyphosate. A lab-scale treatment of simulated glyphosate neutralization liquor obtaining maximum concentrations of $0.45 \mathrm{M}$ for $\mathrm{HCl}$ and $0.6 \mathrm{M}$ for $\mathrm{NaOH}$ was reported (60). The current efficiencies were $45-75 \%$ in a range of current densities 500-1100 A $\cdot \mathrm{m}^{-2}$. The specific energy consumption of the acid was reported to be between 9-18 $\mathrm{kWh} \cdot \mathrm{kg}^{-1}$ of $\mathrm{HCl}$ as a function of the applied current density. A preliminary economic evaluation was also presented with a whole process cost of $1.22-1.82 \$ \cdot \mathrm{kg}^{-1}$ of $\mathrm{HCl}$ and 106.43-158.77 $\$ \cdot \mathrm{m}^{-3}$ of treated liquor. The obtained acid and base could be used for the recovery of the catalyst in the industrial process. Reference (61) deals with the pilot-scale treatment of a glyphosate neutralization liquor. Maximum concentrations of $1.9 \mathrm{M} \mathrm{HCl}$ and 2.4 $\mathrm{M} \mathrm{NaOH}$ were obtained. The energy consumptions for a $2 \mathrm{M} \mathrm{NaOH}$ production was 2.3-3 $\mathrm{kWh} \cdot \mathrm{kg}^{-1} \mathrm{NaOH}$ with current efficiency of $67.9-87.1 \%$ at current densities of 300-600 A $\cdot \mathrm{m}^{-2}$. This work also aims to a zero liquid discharge configuration with a $99 \% \mathrm{NaCl}$ removal and 
recoveries of $96 \%$ of the glyphosate. An evaluation of process economics showed a total process cost of $1.23 \$ \cdot \mathrm{kg}^{-1} \mathrm{NaOH}$ and $165 \$ \cdot \mathrm{ton}^{-1}$ of liquor for a current density of $400 \mathrm{~A} \cdot \mathrm{m}^{-2}$.

A saline water from an integrated mining and metal industry, mainly composed of $\mathrm{NaCl}$ and $\mathrm{KCl}$, was also treated by EDBM for the generation of $\mathrm{HCl}$ and a mixture of $\mathrm{NaOH}$ and $\mathrm{KOH}$ in concentrations around $2 \mathrm{M}$ (62). Removal of $\mathrm{Ca}$ by dosing $\mathrm{Na}_{2} \mathrm{CO}_{3}$ in order to avoid precipitation of $\mathrm{Ca}(\mathrm{OH})_{2}$ in the base compartment was used as pretreatment. The desalination target of $50 \%$ removal of $\mathrm{Cl}^{-}$was easily achieved. A saline wastewater from an industry of metal and metalloid production that mainly contained $\mathrm{NaCl}$ and some organic matter was treated by EDMB (63). $\mathrm{HCl}$ and $\mathrm{NaOH}$ were obtained with a maximum concentration of $1.5 \mathrm{M}$ and $2 \mathrm{M}$ respectively. Two different bipolar membranes were tested: FBM, from Fumasep, and PBM, from Polymer-Chemie. The Fumasep bipolar membrane FBM showed a slightly better electrical resistance and current efficiency. A competition of transport through the anion exchange membrane between chlorides and the organic fraction was observed.

Spent acid solutions from the production of zeolite HZSM-5, mainly composed of $\mathrm{HCl}$ and $\mathrm{NaCl}$, were treated by EDBM (64). Maximum $\mathrm{HCl}$ and $\mathrm{NaOH}$ concentrations of $0.48 \mathrm{M}$ and 0.18 $\mathrm{M}$ were respectively obtained. The faradic current efficiency for $\mathrm{Na}^{+}$regeneration was 27$32 \%$ while the energy consumption was in the range of $12-17 \mathrm{kWh} \cdot \mathrm{kg}^{-1}$ of $\mathrm{NaOH}$ for current densities $350-700 \mathrm{~A} \cdot \mathrm{m}^{-2}$. The regenerated acid could be used to replace the commercial pure acid in the zeolite production (64).

Finally, a combination of nanofiltration and EDBM was used for the treatment of a model textile wastewater. An integrated approach for a simultaneous dye extraction, water recovery and salt 
reuse in the form of $\mathrm{HCl}$ and $\mathrm{NaOH}$ was proposed (65). Maximum concentrations of $1.19 \mathrm{M} \mathrm{HCl}$ and 1.28 $\mathrm{M} \mathrm{NaOH}$ were obtained for an energy consumption of $4.06 \mathrm{kWh} \cdot \mathrm{kg}^{-1}$ of $\mathrm{NaOH}$. The high rejection of nanofiltration for dyes (>99.93\%) avoided fouling in EDBM.

A summary of the main experimental conditions and results for the valorization and treatment of desalination and industrial brines is presented in Table 1.

\section{Technical and economic barriers hindering EDBM development in the production of acids and bases from}

\section{desalination and industrial brine treatment}

The environmental and potential economic benefits of EDBM have been mentioned in previous sections. Nevertheless, some barriers should be overcome before developing the full potential of EDBM in valorization of desalination and industrial brines. Three different kinds of barriers will be screened in this study: technical, techno-economic and economic barriers.

Technical barriers are related to unsolved difficulties that limit the performance of the system (there is a need of a new technical solution to achieve the objective or avoid the limitation). Techno-economic barriers are associated to process optimization and they are usually connected to economic issues (there are difficulties that can be technically solved but adding economic costs). The competitiveness of the technology in the market is linked to the economic barriers (barriers that only depend on the cost of the elements in the market). These three kinds of 
barriers are usually connected to each other. A technical limitation generates a techno-economic barrier that can be translated into additional operation or investment cost and thus an economic barrier or disadvantage for the technology in relation to other technologies.

Most important technical limiting factors of EDBM in comparison to other acid and bases production technologies are related to permselectivity and electro-osmosis. An imperfect permselectivity of IEx membranes causes the migration of co-ions and thus a reduction in purity of the products. Additionally, the selectivity of monopolar membranes decreases when increasing salt concentration. The same happens with the permselectivity of the ion exchange layer of bipolar membranes that decreases with increasing acid and base concentrations, causing high salt contamination of the products at high acid and base concentration (67). Water leakages caused by the electro-osmosis prevent EDBM of producing high concentration of acids or bases (55). Additionally, products have concentration limits due to water electro-osmosis and product diffusion (55). These three technical limitations explain why the acids and bases generated by EDBM cannot reach the specification of commercial products shown in Tables 2 and 3.

Experimentally, the maximum concentrations of $\mathrm{HCl}$ and $\mathrm{NaOH}$ reported have been $1.9 \mathrm{M}$ and $2.4 \mathrm{M}$ respectively $\approx 6 \% \mathrm{w} \cdot \mathrm{w}^{-1}$ and $\approx 8 \% \mathrm{w} \cdot \mathrm{w}^{-1}$ compared to $35 \%$ and $50 \%$ for commercial $\mathrm{HCl}$ and $\mathrm{NaOH}$, respectively). Regarding to impurities, the $\mathrm{SO}_{4}{ }^{2-}$ concentration in $\mathrm{HCl}$ from desalination and industrial brines is two orders of magnitude higher than that in commercial products as shown in Table 2. However, these constraints could be overcome introducing additional purification stages. Nanofiltration has been proposed to remove sulfates in desalination brines (68) but an economic optimization should be performed anyway. 
Additionally, it is pointed out that the concentration of impurities in the $\mathrm{HCl}$ and $\mathrm{NaOH}$ generated by EDBM highly depends on the origin of the brine. The impurities displayed in Table 2 refer to the reported values of impurities from conventional $\mathrm{NaOH}$ and $\mathrm{HCl}$ suppliers. The purity of the products obtained from desalination and industrial brines, and the presence of one impurity or another, will have a strong dependency on the origin of the brine, so new standards of purity might be needed for the commercialization of EDBM produced $\mathrm{HCl}$ and $\mathrm{NaOH}$. These new standards would take into account the purity requirements of the different applications that use $\mathrm{HCl}$ and $\mathrm{NaOH}$ and thus, improvements in the quality of the products would mean an increase in the number of potential applications for the generated $\mathrm{HCl}$ and $\mathrm{NaOH}$.

An alternative to reach commercial grade products by adding purification stages is the in-situ production and consumption of the obtained $\mathrm{HCl}$ and $\mathrm{NaOH}$ since they are both needed chemicals. According to the range of dosage indicated previously (15 to $100 \mathrm{mg} \cdot \mathrm{L}^{-1}$ of $\mathrm{H}_{2} \mathrm{SO}_{4}$, or 11 to $74 \mathrm{mg} \cdot \mathrm{L}^{-1}$ of $\mathrm{HCl}$ for the equivalent $\mathrm{H}^{+}$dose) a range of $0.25-1.69 \mathrm{~L}$ of $\mathrm{HCl} 1.2 \mathrm{M}$ (concentration from (32)) per $\mathrm{m}^{3}$ of stream would be necessary for the treatment of each $\mathrm{m}^{3}$ of feed water. For example, in the cited desalination plant (45\% recovery) of $16,000 \mathrm{~m}^{3}$ seawater $\cdot \mathrm{d}^{-}$ ${ }^{1}$ (31), this corresponds to 4 to $27 \mathrm{~m}^{3} \cdot \mathrm{d}^{-1}$ of $\mathrm{HCl} 1.2 \mathrm{M}$ and the treatment of $8-54 \mathrm{~m}^{3}$ brine $\cdot \mathrm{d}^{-1}$ by EDBM (supposing an initial brine concentration of $70 \mathrm{~g} \cdot \mathrm{L}^{-1} \mathrm{NaCl}$ lowered to $35 \mathrm{~g} \cdot \mathrm{L}^{-1}$ once treated). The purchase of commercial $\mathrm{HCl}\left(28 \% \mathrm{w}^{\cdot} \cdot \mathrm{w}^{-1}\right.$, equivalent to $\left.319 \mathrm{~g} \mathrm{HCl} \cdot \mathrm{L}^{-1}\right)$ at 0.14 $€ \cdot \mathrm{L}^{-1}$ (37) would cost around 77-520 $€ \cdot \mathrm{d}^{-1}$. An important disadvantage of the in-situ consumption and production of $\mathrm{HCl}$ and $\mathrm{NaOH}$ in desalination plants is that only a small fraction of the total volume of the brine generated in the desalination plant would be treated. 
In the case of industrial brines, a very promising scenario is the complete integration of EDBM in the fabrication process with a zero liquid discharge approach $(60,61)$. This means that the treatment of industrial brines is associated with an important consumption of $\mathrm{HCl}$ and $\mathrm{NaOH}$. A possible application for the generated $\mathrm{NaOH}$ could be the post-combustion absorption of $\mathrm{CO}_{2}$. A promising $\mathrm{CO}_{2}$ capture of $530.65 \mathrm{~g} \mathrm{CO}_{2} \cdot \mathrm{kg}^{-1} \mathrm{NaOH} 1.45 \mathrm{M}$ could be achieved if EDBM is powered by renewable energies (69).

The high salt concentration in brines implies some techno-economic limitations. As brines are richer in salts than seawater, scaling of $\mathrm{Ca}$ and $\mathrm{Mg}$ becomes a critical issue. Therefore, a reduction of the water hardness is advisable before brine treatment ((57), (59)). IEx resins have shown adequate effectiveness in the removal of $\mathrm{Ca}$ and $\mathrm{Mg}$ from desalination brines (70). Besides, scaling caused by silica and fouling produced by organic matter content should also be prevented (58) .

Maintaining energy efficiency at high salt concentration and high current density is other technoeconomic challenge that limits the treatment of brines (32). From the summary of the state of the art presented in Table 1 it can be seen that the energy consumption for the production of $\mathrm{HCl}$ and $\mathrm{NaOH}$ from desalination and industrial brines is between 2.3 and $18 \mathrm{kWh} \cdot \mathrm{kg}^{-1}$ of product. The synthesis of new bipolar membranes based on polysulfone and polyvinyl alcohol polymers have shown promising results in terms of current efficiency and energy consumption (71). Leakages of $\mathrm{H}^{+}$and $\mathrm{OH}^{-}$at high product concentration were also related to low energy efficiencies in the production of acids and bases (59). Additionally, ion exchange membranes are known to have 
poor stability in strong acids and bases, which leads to a decrease in membrane lifetime and affects the economical viability of the process (67).

Currently, the main economic barrier of EDBM is the high investment cost of both electrodes and membranes, and especially bipolar membranes $(67,72)$. The price of bipolar membranes is a bottleneck that prevents EDBM from large-scale applications. The cost of bipolar membranes can be estimated around $0.1 € \cdot \mathrm{cm}^{-2}$ (73), which is 3-10 times more expensive than monopolar membranes (55). This cost difference is mainly due to the more complicated manufacturing process and smaller scale BM production. The cost of heterogeneous bipolar membranes is reported to be between 2-4 times lower than conventional homogeneous membranes; however, the lower selectivity of these membranes might compromise the purity of the obtained products (74).

Another factor is the limited choice of membranes and suppliers for EDBM applications (73). This is a disadvantage compared to other technologies in terms of technical support (75). This limited choice of BM suppliers in relation to ion exchange membranes is also seen in the EDBM literature. While for cation and anion exchange membranes the references reviewed in this work used a variety of commercially available membranes from different suppliers (for example RALEX, Fumatech, Qianqui Environmental protection and water treatment co., Polymer-Chemie and Neosepta), there is a single supplier of BM membranes. The membrane Fumasep from Fumatech is the one used in most cases, with only a couple of exceptions that used a bipolar membrane from Neosepta (BP-1) and Polymer-Chemie. This difference of membrane availability can also be realized by comparing the list of commercial membranes and suppliers 
published in several reviews about electrodialysis with bipolar membranes (55) and ion exchange membranes $(76,77)$.

The investment cost is still relatively high because there is no large-scale production of membranes. This is the main reason explaining why there is such a small number of large-scale EDBM plants, despite the technical and economic advantages of the EDBM technology $(62,78)$. In Figure 2, a summary of the main barriers previously described for the production of acids and bases by EDBM is presented.

\section{Conclusions}

The vast amount of brines generated in several activities, such as the desalination industry, encourages the need of innovative processes aimed not only to reduce the environmental impact but also to recover and to valorize resources contained in the brines.

In this work, a study of the state of the art regarding the use of Electrodialysis with Bipolar Membranes (EDBM) in the valorization of brines has been presented. EDBM is a viable technology for obtaining acids $(\mathrm{HCl})$ and bases $(\mathrm{NaOH})$ from the salts contained in the brines ready for scale-up. Although the concentration and quality of the obtained products are strongly influenced by the feed water composition, they are acceptable for self-supply in desalination and different industrial activities. The purity and concentration requested by commercial grade products remains a challenge. Regarding to the use of the obtained products, even if a large dosage of $\mathrm{HCl}$ is used for different applications within a desalination plant, estimations state that around only $1 \%$ in terms of the input feed stream to RO treated by EDBM is sufficient for self- 
supply. This fact together to the mentioned quality promotes that a commercial grade product must be pursued. On the other hand, the integration of EDBM with some industrial processes, responsible for the generation of brines and consumption of large quantities of $\mathrm{NaOH}$ and $\mathrm{HCl}$, such as the production of glyphosate, are a very promising alternative for the in-situ production and consumption of $\mathrm{HCl}$ and $\mathrm{NaOH}$ because much more higher internal demand.

Regarding the main barriers for a larger penetration of EDBM technology, the main bottlenecks to overcome have been identified in this work, pointing the current research areas of interest. Significant improvement of the selectivity of ion exchange membranes and limitation of electroosmosis phenomena associated with this specific application would lead to higher purity in obtained products and would increase the energy efficiency of the recovery process. Consequently, products of commercial grade quality could be obtained for further commercialization as opposite to the current situation. Additionally, the $\mathrm{HCl}$ and $\mathrm{NaOH}$ purity improvement combined with the definition of new standards of quality for the obtained products, directly related to the purity requirements of each specific use, would lead to an increase in the number of applications where these acids and bases could be used. Finally, the high cost of bipolar membranes (around 1,000 $€ \cdot \mathrm{m}^{-2}$ ) makes the investment costs of EDBM still relatively high compared to other membrane technologies hindering its development. 


\section{Acknowledgements}

The authors gratefully acknowledge the funding for the projects CTQ2013-48280-C3-1-R-D and CTM2014-57833-R. Carolina Fernandez-Gonzalez also thanks the Spanish Ministry of Economy and Competitiveness for the FPI grant awarded BES-2012-053461.

\section{References}

[1] Lior N. Advances in Water Desalination. John Wiley \& Sons; 2012.

[2] Sethi, S., Walker, S, Drewes, J,Xu, P. (2006) Existing and Emerging Concentrate Minimization and Disposal Practices for Membrane Systems. Fla Water Resour J, 58: 38-48.

[3] Greenlee, L.F., Lawler, DF, Freeman, BD, Marrot, B,Moulin, P. (2009) Reverse Osmosis Desalination: Water Sources, Technology, and Today's Challenges. Water Res, 43: 2317-2348.

[4] Ahmed, M., Shayya, WH, Hoey, D, Mahendran, A, Morris, R,Al-Handaly, J. (2000) Use of Evaporation Ponds for Brine Disposal in Desalination Plants. Desalination, 130: 155-168.

[5] Muniz, A.,Skehan, S. (1990) Disposal of Concentrate from Brackish Water Desalting Plants by use of Deep Injection Wells. Desalination, 78: 41-47.

[6] Purnalna, A., Al-Barwani, HH,Al-Lawatia, M. (2003) Modeling Dispersion of Brine Waste Discharges from a Coastal Desalination Plant. Desalination, 155: 41-47.

[7] Bashitialshaaer, R., Flyborg, L,Persson, KM. (2011) Environmental Assessment of Brine Discharge and Wastewater in the Arabian Gulf. Desalin Water Treat, 25: 276-285. 
[8] Nghiem, L.D.,Robertson, A. (2011) Treatment of High TDS Liquid Waste: Is Zero Liquid Discharge Feasible? Faculty of Engineering-Papers, 1-11.

[9] Katzir, L., Volkmann, Y, Daltrophe, N, Korngold, E, Mesalem, R, Oren, Y,Gilron, J. (2010) WAIV - Wind Aided Intensified Evaporation for Brine Volume Reduction and Generating Mineral Byproducts. Desalin Water Treat, 13: 63-73.

[10] Younos, T. (2005) Environmental Issues of Desalination. J Contemp Water Res Edu, 132: 11-18.

[11] Greenlee, L.F., Lawler, DF, Freeman, BD, Marrot, B,Moulin, P. (2009) Reverse Osmosis Desalination: Water Sources, Technology, and Today's Challenges. Water Res, 43: 2317-2348.

[12] Einav, R., Harussi, K,Perry, D. (2003) The Footprint of the Desalination Processes on the Environment. Desalination, 152: 141-154.

[13] Roberts, D.A., Johnston, EL,Knott, NA. (2010) Impacts of Desalination Plant Discharges on the Marine Environment: A Critical Review of Published Studies. Water Res, 44: 5117-5128.

[14] Alharbi, O.A., Phillips, MR, Williams, AT, Gheith, AM, Bantan, RA,Rasul, NM. (2012) Desalination Impacts on the Coastal Environment: Ash Shuqayq, Saudi Arabia. Sci Total Environ, 421-422: 163-172.

[15] Liu, T., Sheu, H,Tseng, C. (2013) Environmental Impact Assessment of Seawater Desalination Plant Under the Framework of Integrated Coastal Management. Desalination, 326: $10-18$. 
[16] Ning, X.-., Lin, M-, Shen, L-, Zhang, J-, Wang, J-, Wang, Y-, Yang, Z-,Liu, J-. (2014)

Levels, Composition Profiles and Risk Assessment of Polycyclic Aromatic Hydrocarbons (PAHs) in Sludge from Ten Textile Dyeing Plants. Environ. Res., 132: 112-118.

[17] Pérez-González, A., Urtiaga, AM, Ibáñez, R,Ortiz, I. (2012) State of the Art and Review on the Treatment Technologies of Water Reverse Osmosis Concentrates. Water Res, 46: 267-283.

[18] Morillo, J., Usero, J, Rosado, D, El Bakouri, H, Riaza, A,Bernaola, F. (2014) Comparative Study of Brine Management Technologies for Desalination Plants. Desalination, 336: 32-49.

[19] Kim, D.H. (2011) A Review of Desalting Process Techniques and Economic Analysis of the Recovery of Salts from Retentates. Desalination, 270: 1-8.

[20] Van Der Bruggen, B., Lejon, L,Vandecasteele, C. (2003) Reuse, Treatment, and Discharge of the Concentrate of Pressure-Driven Membrane Processes. Environ Sci Technol, 37: 37333738.

[21] Leong, J., Tan, J, Charrois, J,Ladewig, BP. (2013) Review of High Recovery Concentrate Management Options. Desalin Water Treat, 52: 7609-7627.

[22] Xu, P., Cath, TY, Robertson, AP, Reinhard, M, Leckie, JO,Drewes, JE. (2013) Critical Review of Desalination Concentrate Management, Treatment and Beneficial use. Environ. Eng. Sci., 30: 502-514.

[23] Tran, A.T.K., Mondal, P, Lin, J, Meesschaert, B, Pinoy, L,Van der Bruggen, B. (2015) Simultaneous Regeneration of Inorganic Acid and Base from a Metal Washing Step Wastewater by Bipolar Membrane Electrodialysis After Pretreatment by Crystallization in a Fluidized Pellet Reactor. J. Membr. Sci., 473: 118-127. 
[24] Wei, Y., Wang, Y, Zhang, X,Xu, T. (2013) Comparative Study on the Treatment of Simulated Brominated Butyl Rubber Wastewater by using Bipolar Membrane Electrodialysis (BMED) and Conventional Electrodialysis (ED). Sep. Purif. Technol., 110: 164-169.

[25] Kumar, H.,Alén, R. (2014) Partial Recovery of Aliphatic Carboxylic Acids and Sodium Hydroxide from Hardwood Black Liquor by Electrodialysis. Ind Eng Chem Res, 53: 9464-9470.

[26] Lameloise, M.-.,Lewandowski, R. (2012) Recovering l-Malic Acid from a Beverage Industry Waste Water: Experimental Study of the Conversion Stage using Bipolar Membrane Electrodialysis. J. Membr. Sci., 403-404: 196-202.

[27] Zhang, X., Li, C, Wang, Y, Luo, J,Xu, T. (2011) Recovery of Acetic Acid from Simulated Acetaldehyde Wastewaters: Bipolar Membrane Electrodialysis Processes and Membrane Selection. J. Membr. Sci., 379: 184-190.

[28] Lattemann, S.,Höpner, T. (2008) Environmental Impact and Impact Assessment of Seawater Desalination. Desalination, 220: 1-15.

[29] Al-Shammiri, M., Safar, M,Al-Dawas, M. (2000) Evaluation of Two Different Antiscalants in Real Operation at the Doha Research Plant. Desalination, 128: 1-16.

[30] United Nations Environmental Programme (UNEP) (2008) Desalination Resource and Guidance Manual for Environmental Impact Assessments, UNEP/ROWA, Manama, and WHO/EMRO.

[31] Sadhwani, J.J., Veza, JM,Santana, C. (2005) Case Studies on Environmental Impact of Seawater Desalination. Desalination, 185: 1-8. 
[32] Yang, Y., Gao, X, Fan, A, Fu, L,Gao, C. (2014) An Innovative Beneficial Reuse of Seawater Concentrate using Bipolar Membrane Electrodialysis. J Membrane Sci, 449: 119-126.

[33] Mezher, T., Fath, H, Abbas, Z,Khaled, A. (2011) Techno-Economic Assessment and Environmental Impacts of Desalination Technologies. Desalination, 266: 263-273.

[34] Seawater Desalination Costs. White Paper. (2012) Water Reuse Association,.

[35] Klaus-Viktor Peinemann and Suzana Pereira Nunes.Membranes for Water Treatment: Volume 4.Weinheim:WILEY-VCH. ISBN:978-3-527-31483-6;2010.

[36] El-Sheikh, R., Shaban, M,Jaber, I. Management of desalination plants and distribution options of desalinated water. Available at http://iwtc.info/wpcontent/uploads/2010/09/Management-of-desalination-plants-and-distribution-options-ofdesalinated-water.pdf (Accessed November 16, 2015)

[37] Zhang, Y., Ghyselbrecht, K, Vanherpe, R, Meesschaert, B, Pinoy, L,Van der Bruggen, B. (2012) RO Concentrate Minimization by Electrodialysis: Techno-Economic Analysis and Environmental Concerns. J Environ Manage, 107: 28-36.

[38] Safrai, I.,Zask, A. (2008) Reverse Osmosis Desalination Plants — Marine Environmentalist Regulator Point of View. Desalination, 220: 72-84.

[39] Ghaffour, N., Missimer, TM,Amy, GL. (2013) Technical Review and Evaluation of the Economics of Water Desalination: Current and Future Challenges for Better Water Supply Sustainability. Desalination, 309: 197-207. 
[40] Del-Pilar-Ruso, Y., De-la-Ossa-Carretero, JA, Giménez-Casalduero, F,Sánchez-Lizaso, JL. (2008) Effects of a Brine Discharge Over Soft Bottom Polychaeta Assemblage. Environ Pollut, 156: $240-250$.

[41] Miri, R.,Chouikhi, A. (2005) Ecotoxicological Marine Impacts from Seawater Desalination Plants. Desalination, 182: 403-410.

[42] Mauguin, G.,Corsin, P. (2005) Concentrate and Other Waste Disposals from SWRO Plants: Characterization and Reduction of their Environmental Impact. Desalination, 182: 355-364.

[43] Sánchez-Lizaso, J.L., Romero, J, Ruiz, J, Gacia, E, Buceta, JL, Invers, O, Fernández Torquemada, Y, Mas, J, Ruiz-Mateo, A,Manzanera, M. (2008) Salinity Tolerance of the Mediterranean Seagrass Posidonia Oceanica: Recommendations to Minimize the Impact of Brine Discharges from Desalination Plants. Desalination, 221: 602-607.

[44] Elimelech, M.,Phillip, WA. (2011) The Future of Seawater Desalination: Energy, Technology, and the Environment. Science, 333: 712-717.

[45] Abu Qdais, H. (2008) Environmental Impacts of the Mega Desalination Project: The RedDead Sea Conveyor. Desalination, 220: 16-23.

[46] Tsiourtis, N.X. (2001)Desalination and the Environment. Desalination, 141: 223-236.

[47] European commision Environment:http://ec.europa.eu/environment/eia/eialegalcontext.htm. (Accessed November 16, 2015)

[48] Stokes, J.,Horvath, A. (2006) Life Cycle Energy Assessment of Alternative Water Supply Systems. Int J Life Cycle Ass, 11: 335-343. 
[49] Del Borghi, A., Strazza, C, Gallo, M, Messineo, S,Naso, M. (2013) Water Supply and Sustainability: Life Cycle Assessment of Water Collection, Treatment and Distribution Service. Int J Life Cycle Ass, 18: 1158-1168.

[50] Xu, T. (2005) Ion Exchange Membranes: State of their Development and Perspective. $J$ Membrane Sci, 263: 1-29.

[51] Mier, M.P., Ibañez, R,Ortiz, I. (2008) Influence of Ion Concentration on the Kinetics of Electrodialysis with Bipolar Membranes. Sep Purif Technol, 59: 197-205.

[52] Fernandez-Gonzalez, C., Dominguez-Ramos, A, Ibañez, R,Irabien, A. (2015) Sustainability Assessment of Electrodialysis Powered by Photovoltaic Solar Energy for Freshwater Production. Renew Sust Energ Rev, 47: 604-615.

[53] Kentish, S.E., Kloester, E, Stevens, GW, Scholes, CA,Dumée, LF. (2015) Electrodialysis in Aqueous-Organic Mixtures. Sep Purif Rev, 44: 269-282.

[54] Kumar, M., Khan, MA, Al-Othman, ZA,Choong, TSY. (2013) Recent Developments in IonExchange Membranes and their Applications in Electrochemical Processes for in Situ Ion Substitutions, Separation and Water Splitting. Sep Purif Rev, 42: 187-261.

[55] Huang, C.,Xu, T. (2006) Electrodialysis with Bipolar Membranes for Sustainable Development. Environ Sci Technol, 40: 5233-5243.

[56] Badruzzaman, M., Oppenheimer, J, Adham, S,Kumar, M. (2009) Innovative Beneficial Reuse of Reverse Osmosis Concentrate using Bipolar Membrane Electrodialysis and Electrochlorination Processes. J Membrane Sci, 326: 392-399. 
[57] Ibáñez, R., Pérez-González, A, Gómez, P, Urtiaga, AM,Ortiz, I. (2013) Acid and Base Recovery from Softened Reverse Osmosis (RO) Brines. Experimental Assessment using Model Concentrates. Desalination, 309: 165-170.

[58] Mavrov, V., Chmiel, H, Heitele, B,Rögener, F. (1999) Desalination of Surface Water to Industrial Water with Lower Impact on the Environment: Part 4: Treatment of Effluents from Water Desalination Stages for Reuse and Balance of the New Technological Concept for Water Desalination. Desalination, 124: 205-216.

[59] Wang, M., Wang, K, Jia, Y,Ren, Q. (2014) The Reclamation of Brine Generated from Desalination Process by Bipolar Membrane Electrodialysis. J Membrane Sci, 452: 54-61.

[60] Wang, X.-., Wang, M, Jia, Y-,Yao, T-. (2012) The Feasible Study on the Reclamation of the Glyphosate Neutralization Liquor by Bipolar Membrane Electrodialysis. Desalination, 300: 5863.

[61] Shen, J., Huang, J, Liu, L, Ye, W, Lin, J,Van der Bruggen, B. (2013) The use of BMED for Glyphosate Recovery from Glyphosate Neutralization Liquor in View of Zero Discharge. $J$. Hazard. Mater., 260: 660-667.

[62] Ghyselbrecht, K., Huygebaert, M, Van der Bruggen, B, Ballet, R, Meesschaert, B,Pinoy, L. (2013) Desalination of an Industrial Saline Water with Conventional and Bipolar Membrane Electrodialysis. Desalination, 318: 9-18.

[63] Ghyselbrecht, K., Silva, A, Van der Bruggen, B, Boussu, K, Meesschaert, B,Pinoy, L. (2014) Desalination Feasibility Study of an Industrial NaCl Stream by Bipolar Membrane Electrodialysis. J. Environ. Manage., 140: 69-75. 
[64] Gao, X., Yang, Y, Fu, L, Sun, Z, Zheng, Y,Gao, C. (2014) Regenerating Spent Acid Produced by HZSM-5 Zeolite Preparation by Bipolar Membrane Electrodialysis. Sep. Purif. Technol., 125: 97-102.

[65] Davis, J.R., Chen, Y, Baygents, JC,Farrell, J. (2015) Production of Acids and Bases for Ion Exchange Regeneration from Dilute Salt Solutions using Bipolar Membrane Electrodialysis. ACS Sustainable Chem. Eng., 3: 2337-2342.

[66] Lin, J., Ye, W, Huang, J, Ricard, B, Baltaru, M-, Greydanus, B, Balta, S, Shen, J, Vlad, M, Sotto, A, Luis, P,Van Der Bruggen, B. (2015) Toward Resource Recovery from Textile Wastewater: Dye Extraction, Water and Base/Acid Regeneration using a Hybrid NF-BMED Process. ACS Sustainable Chem. Eng., 3: 1993-2001.

[67] Strathmann, H. (2010) Electrodialysis, a Mature Technology with a Multitude of New Applications. Desalination, 264: 268-288.

[68] Pérez-González, A., Ibáñez, R, Gómez, P, Urtiaga, AM, Ortiz, I,Irabien, JA. (2015) Nanofiltration Separation of Polyvalent and Monovalent Anions in Desalination Brines. $J$. Membr. Sci., 473: 16-27.

[69] Ye, W., Huang, J, Lin, J, Zhang, X, Shen, J, Luis, P,Van Der Bruggen, B. (2015) Environmental Evaluation of Bipolar Membrane Electrodialysis for $\mathrm{NaOH}$ Production from Wastewater: Conditioning NaOH as a CO2 Absorbent. Sep. Purif. Technol., 144: 206-214.

[70] Pérez-gonzález, A., Ibáñez, R, Gómez, P, Urtiaga, A, Ortiz, I,Irabien, J. (2014) Recovery of Desalination Brines: Separation of Calcium, Magnesium and Sulfate as a Pre-Treatment Step. Desalin Water Treat, doi: 10.1080/19443994.2014.973454. 
[71] Venugopal, K.,Dharmalingam, S. (2012) Desalination Efficiency of a Novel Bipolar Membrane Based on Functionalized Polysulfone. Desalination, 296: 37-45.

[72] Xu, T.,Huang, C. (2008) Electrodialysis-Based Separation Technologies: A Critical Review. AIChE J., 54: 3147-3159.

[73] Fumatech:http://www.fumatech.com/EN/. (Accessed November 16, 2015)

[74] Zabolotskii, V., Sheldeshov, N,Melnikov, S. (2014) Heterogeneous Bipolar Membranes and their Application in Electrodialysis. Desalination, 342: 183-203.

[75] Burges, K. (2003) Pv Powered Desalination. The Middle East Desalination Research Centre (MEDRC),

[76] Xu, T. (2005) Ion Exchange Membranes: State of their Development and Perspective. $J$. Membr. Sci., 263: 1-29.

[77] Kim, D.J., Jeong, MK,Nam, SY. (2015) Research Trends in Ion Exchange Membrane Processes and Practical Applications. Appl. Chem. Eng., 26: 1-16.

[78] Tongwen, X. (2002) Electrodialysis Processes with Bipolar Membranes (EDBM) in Environmental Protection - A Review. Resour Conserv Recy, 37: 1-22.

[79] Technical and food grade hydrochloric acid.PCC Morava Chem:http://www.pccmoravachem.cz/ttw/mch.nsf/id/EN_Hydrochloric_acid_\%28food_grade,_technical_grade\%29

(Accessed November 16, 2015) 
[80] High purity hydrochloric acid.Hubei

Sanonda:http://www.sld.chemchina.com/slden/cpyfw/ppysb/chjyzyhxp/webinfo/2012/07/134261 1934400944.htm (Accessed November 16, 2015)

[81] Muriatic Acid.

PPG:http://www.ppg.com/chemicals/chloralkali/documents/english/muriaticacid.pdf (Accessed November 16, 2015)

[82] Food grade Hydrochloric acid 20 degree. Reagent

chemical:http://www.reagentchemical.com/documents/HCL_Food_Grade_20.pdf (Accessed November 16, 2015)

[83] Food grade Hydrochloric acid 22 degree. Reagent chemical:http://www.reagentchemical.com/documents/HCL_Food_Grade_22.pdf (Accessed November 16, 2015)

[84] Liquid Caustic soda. Covestro:

http://www.polyurethanes.covestro.com/Handler/GenericForceDownload.ashx?itemID=C5BD0 BD550D2441DAA28177D1BA4E756\&lang=en (Accessed November 16, 2015)

[85] Commercial grade caustic soda. Colonial Chemical Solutions:

http://colonialchemicals.com/uploads/Products/Caustic\%20Soda\%20-

\%20Rayon\%20Grade/Caustic\%20Soda\%20RG_Tech.pdf (Accessed November 16, 2015)

[86] Membrane Cell Caustic Soda. NPC Chlorochem:

http://www.ncp.co.za/product/detail/2/caustic-soda-lye-naoh (Accessed November 16, 2015) 
[87] Diaphragmn cell and membrane cell Caustic Soda. Olin: http://www.olinchloralkali.com/enus/ (Accessed November 16, 2015)

[88] High purity sodium hydroxide. Siping Haohua Chemical:http://www.hhsp.chemchina.com/sphhen/cpyfw/ppysb/webinfo/2012/05/13390608949 28029.htm (Accessed November 16, 2015) [89] Caustic Soda Liquid. Vinythai: http://www.solvay.com/en/index.html (Accessed November 16, 2015) 
Figure 1. Operation scheme of EDBM for the production of acids and bases from $\mathrm{NaCl}$.

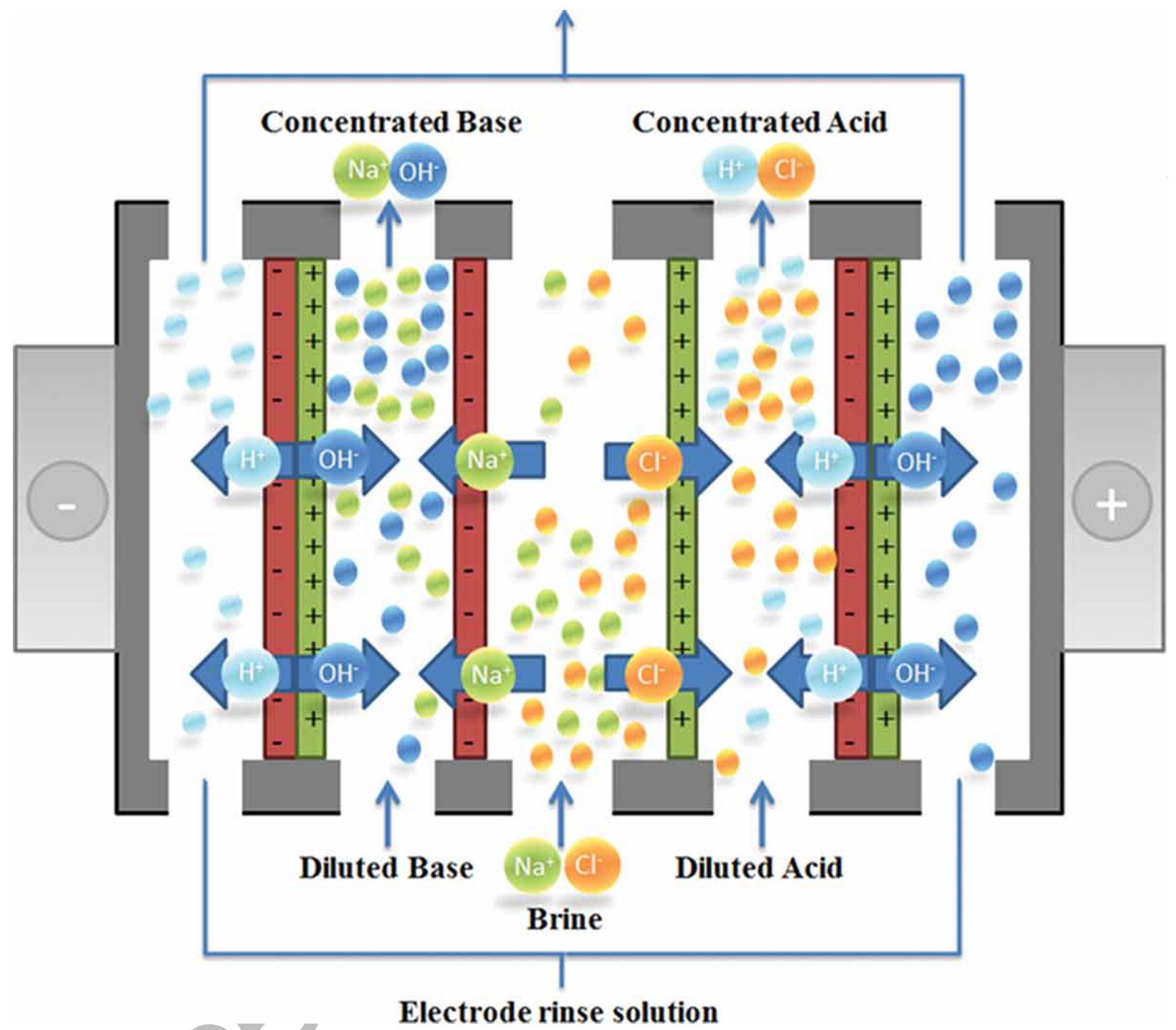


Figure 2. Summary of the main barriers for the production of acids and bases by EDBM.

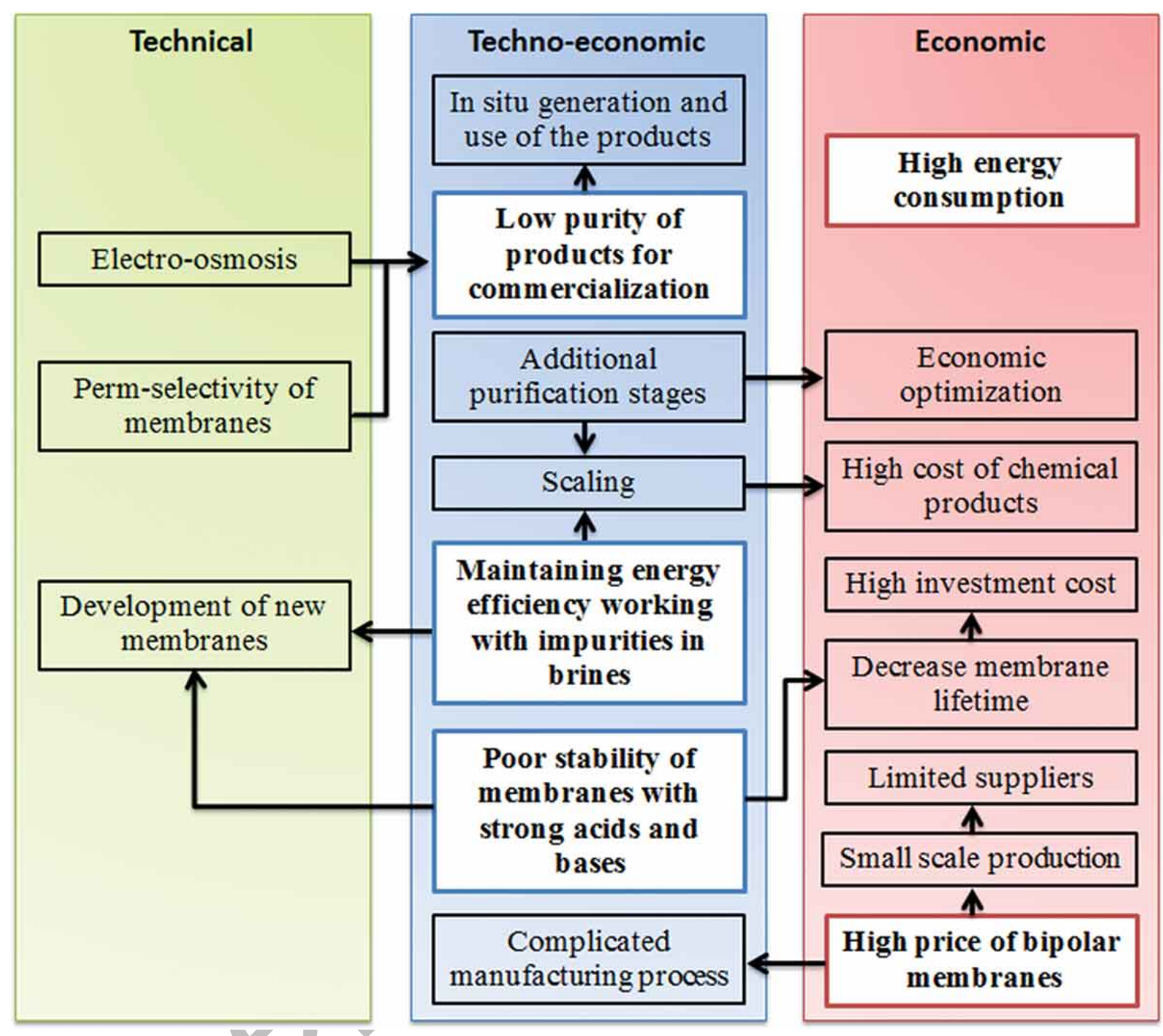


Table 1. Summary of the main results and references dealing with the valorization of brines into $\mathrm{HCl}$ and $\mathrm{NaOH}$.

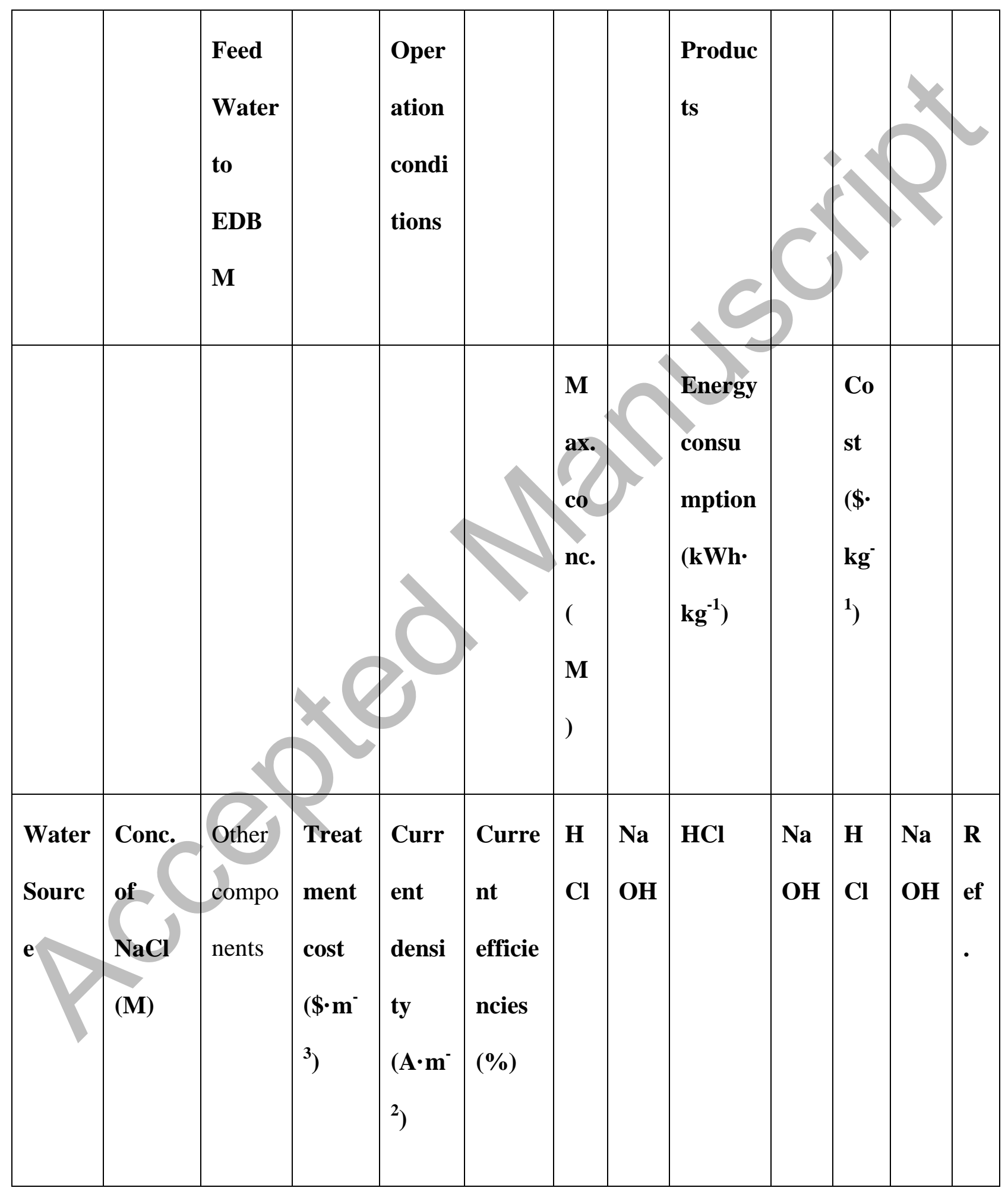




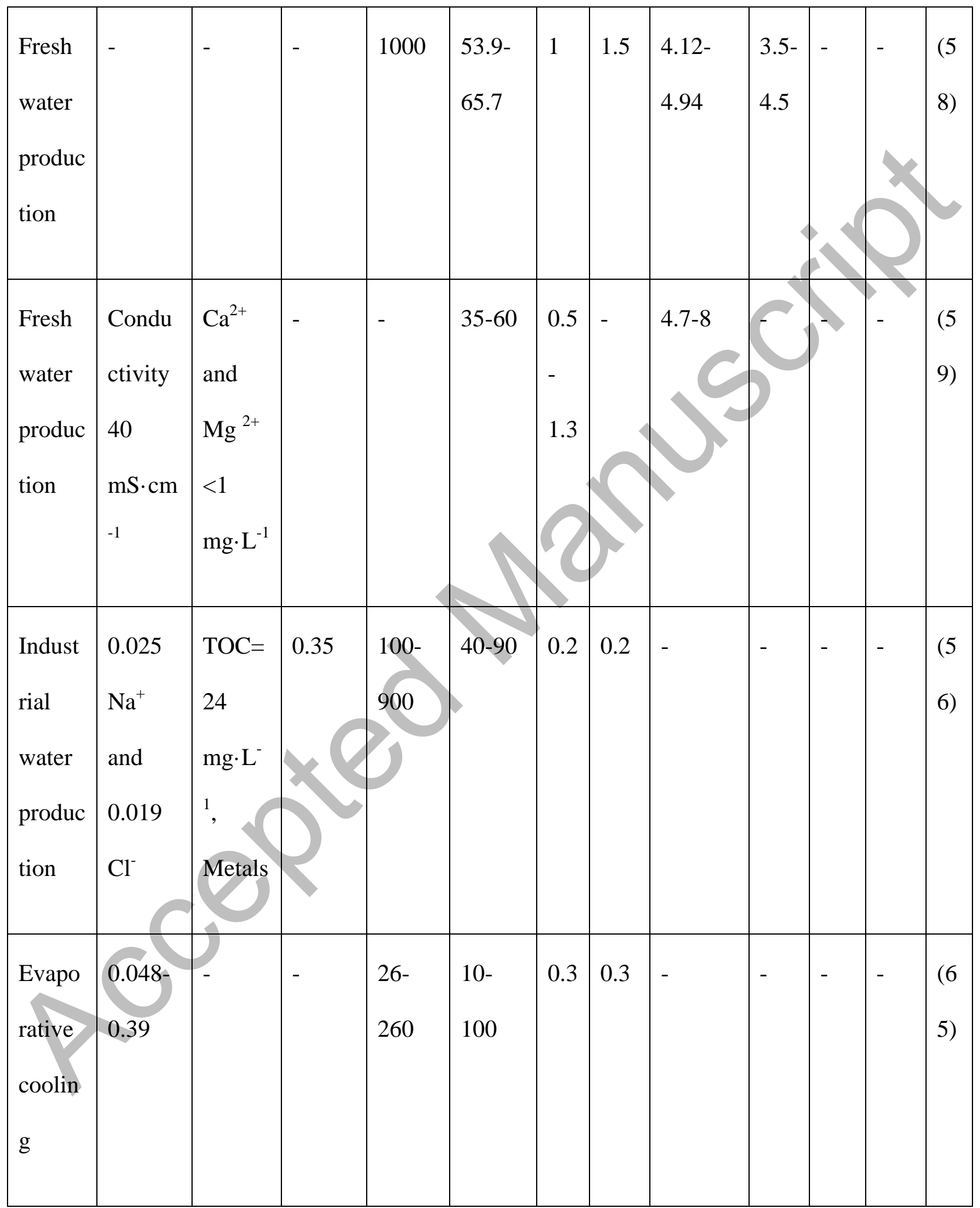



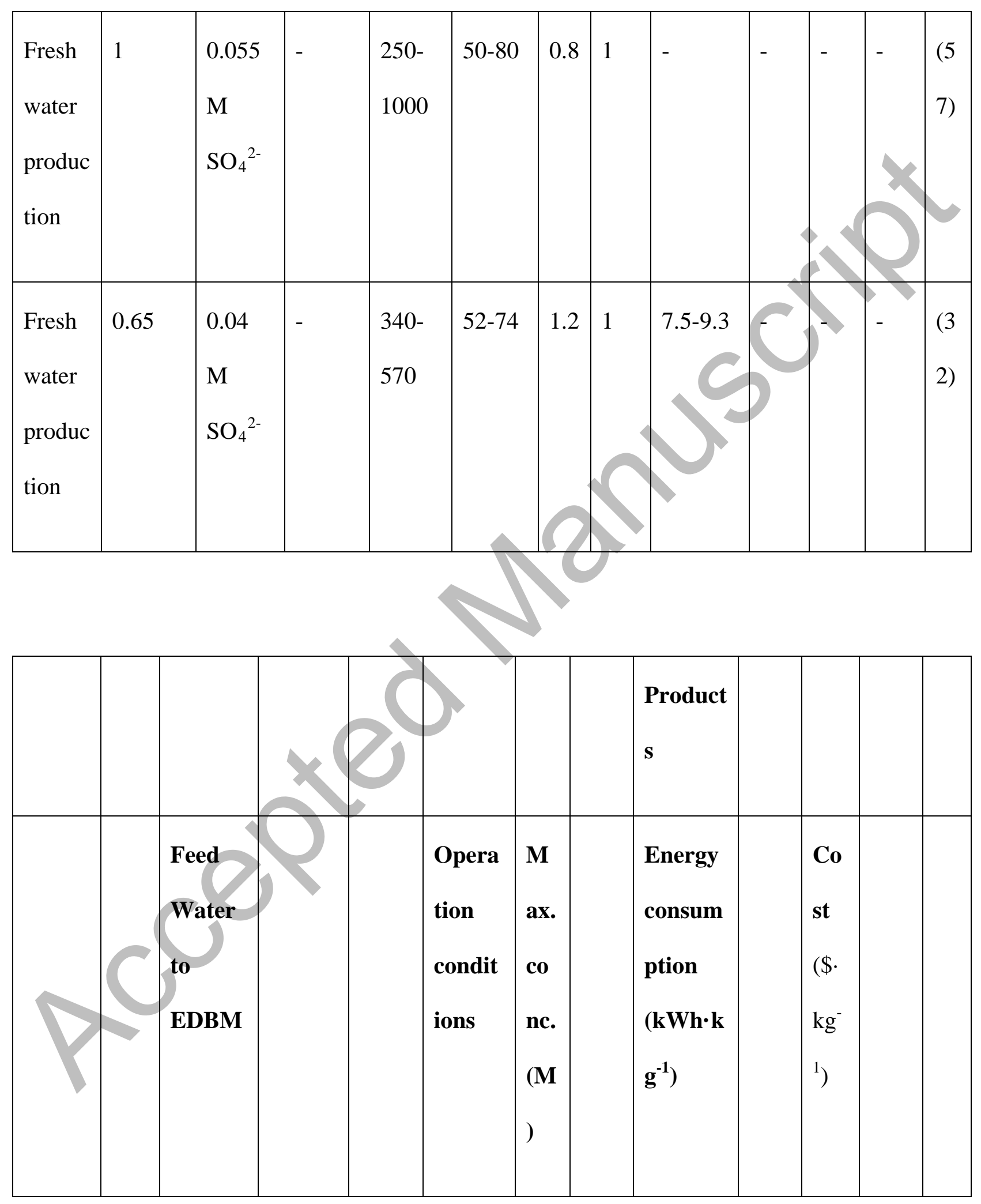


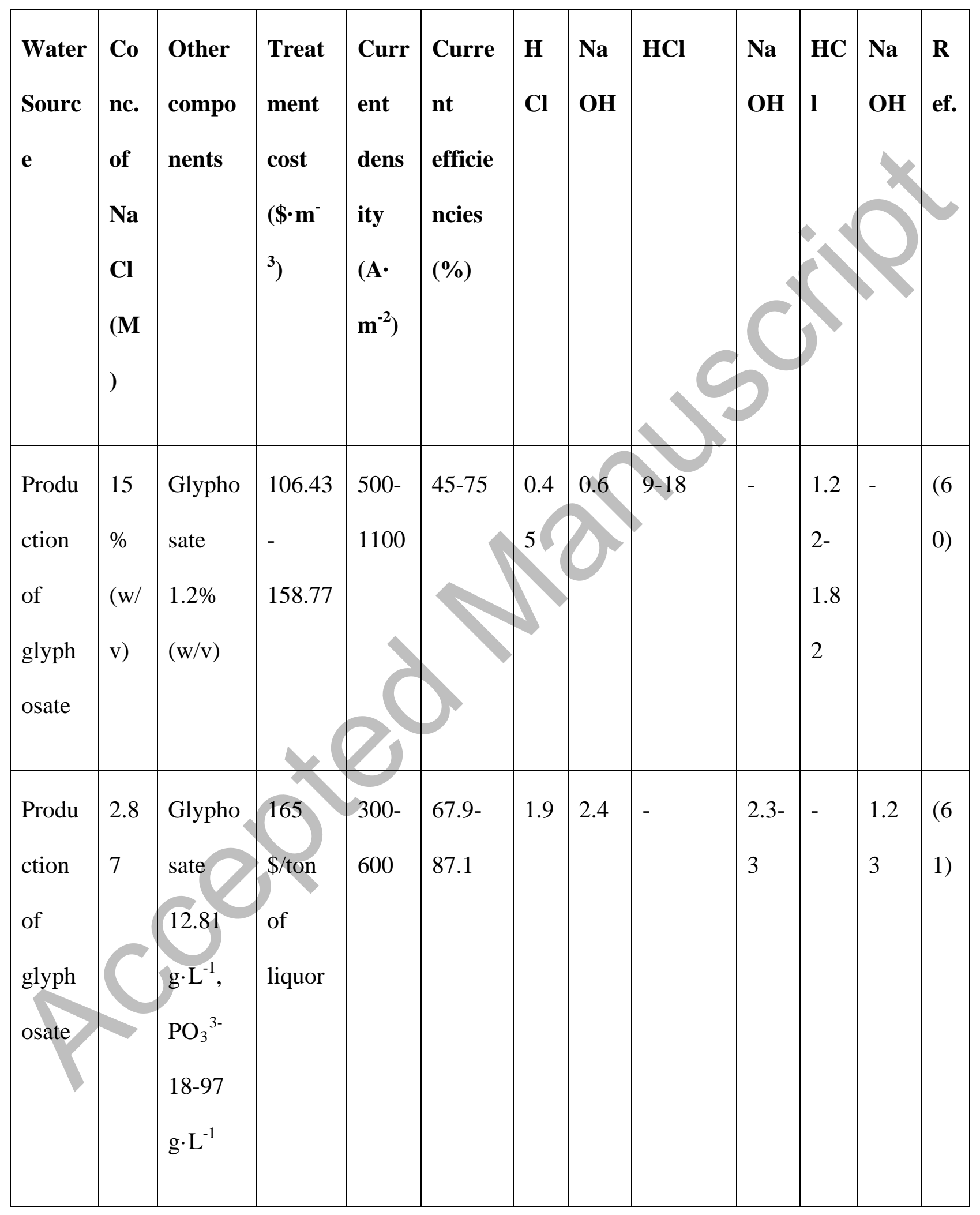




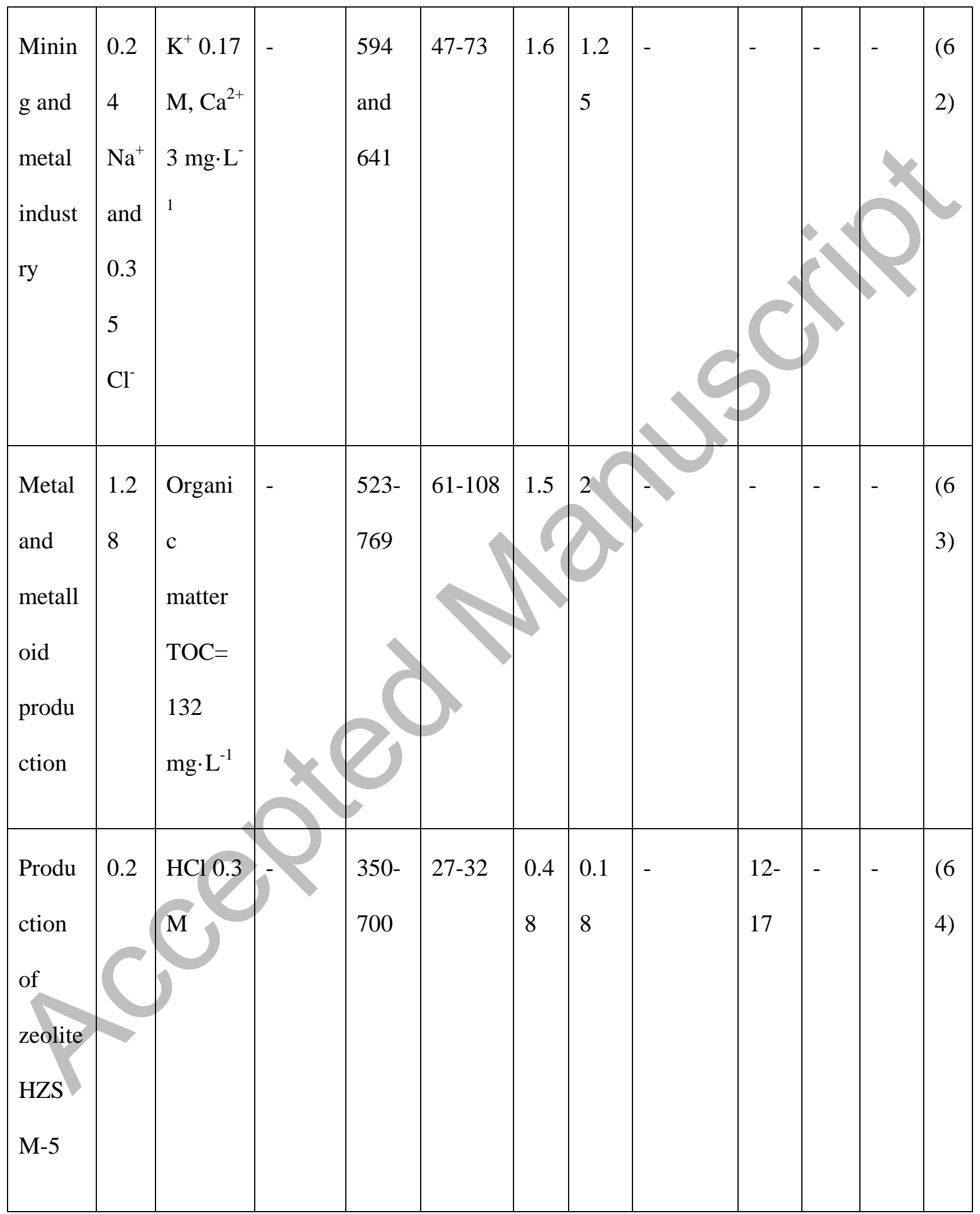




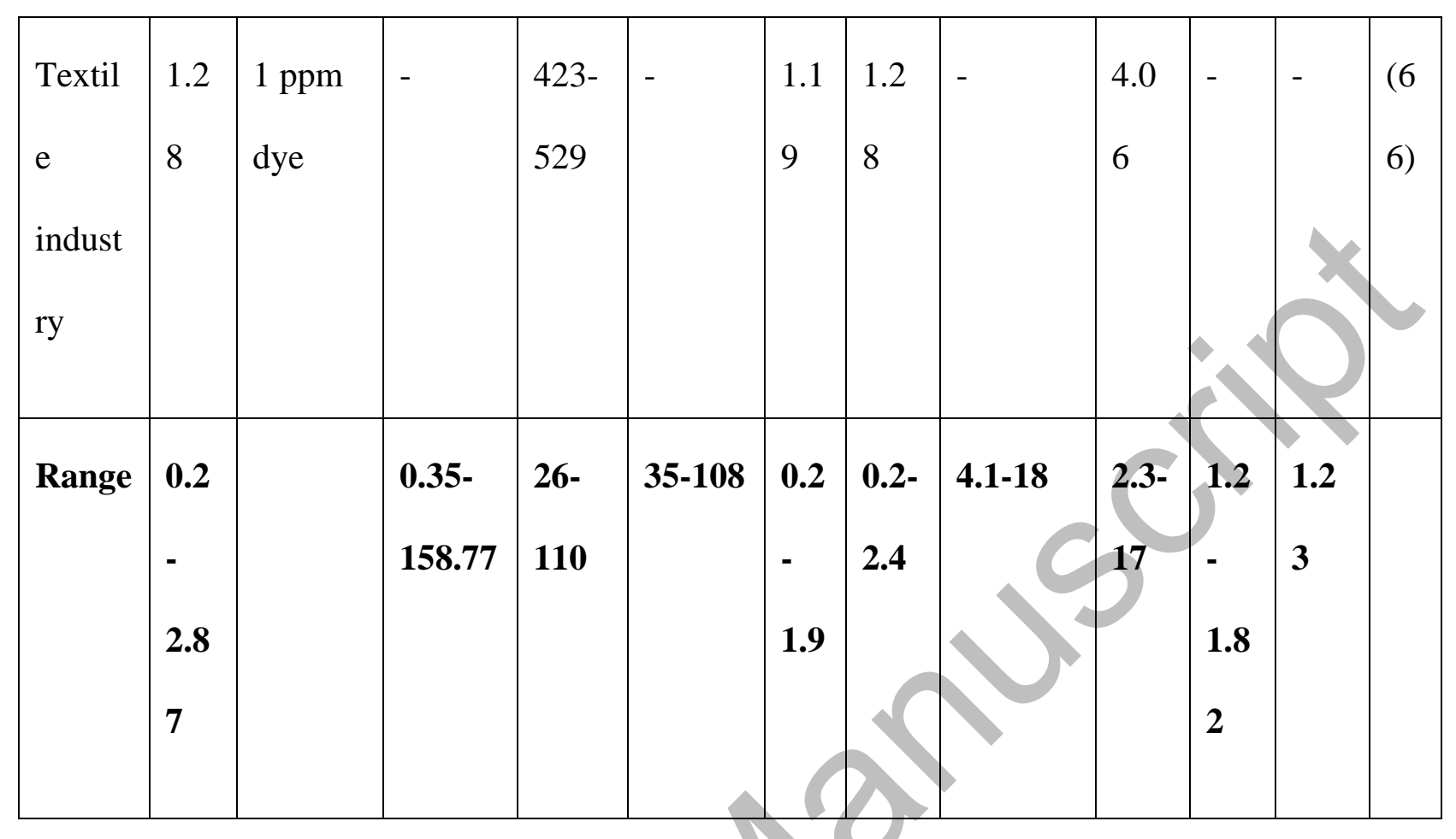


Table 2. Maximum concentration of impurities allowed in different commercial grades of $\mathrm{HCl}$ compared to self-supply by EDBM. If not specified, concentration of impurities is expressed in $\mathrm{mg} \cdot \mathrm{L}^{-1}$.

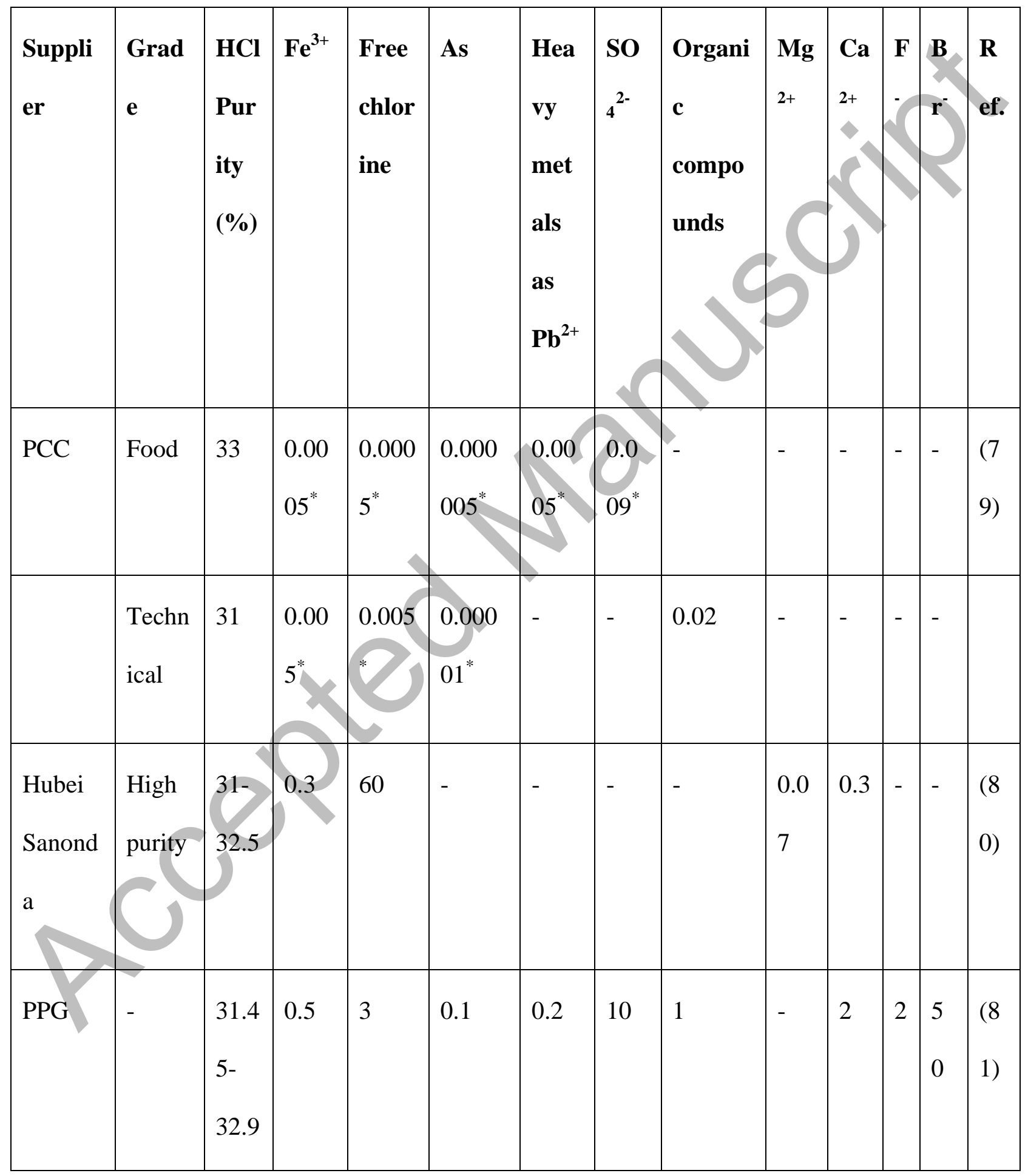




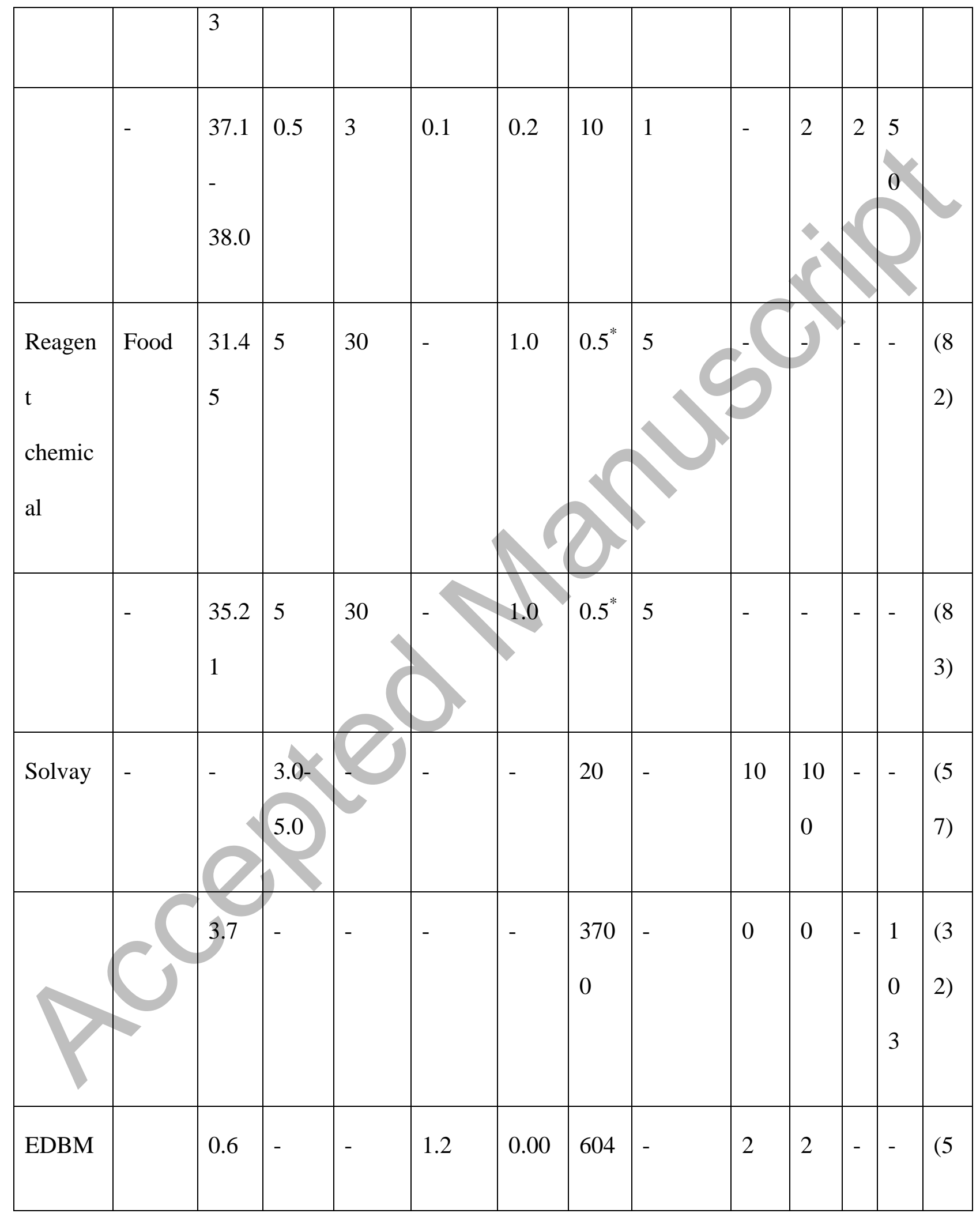




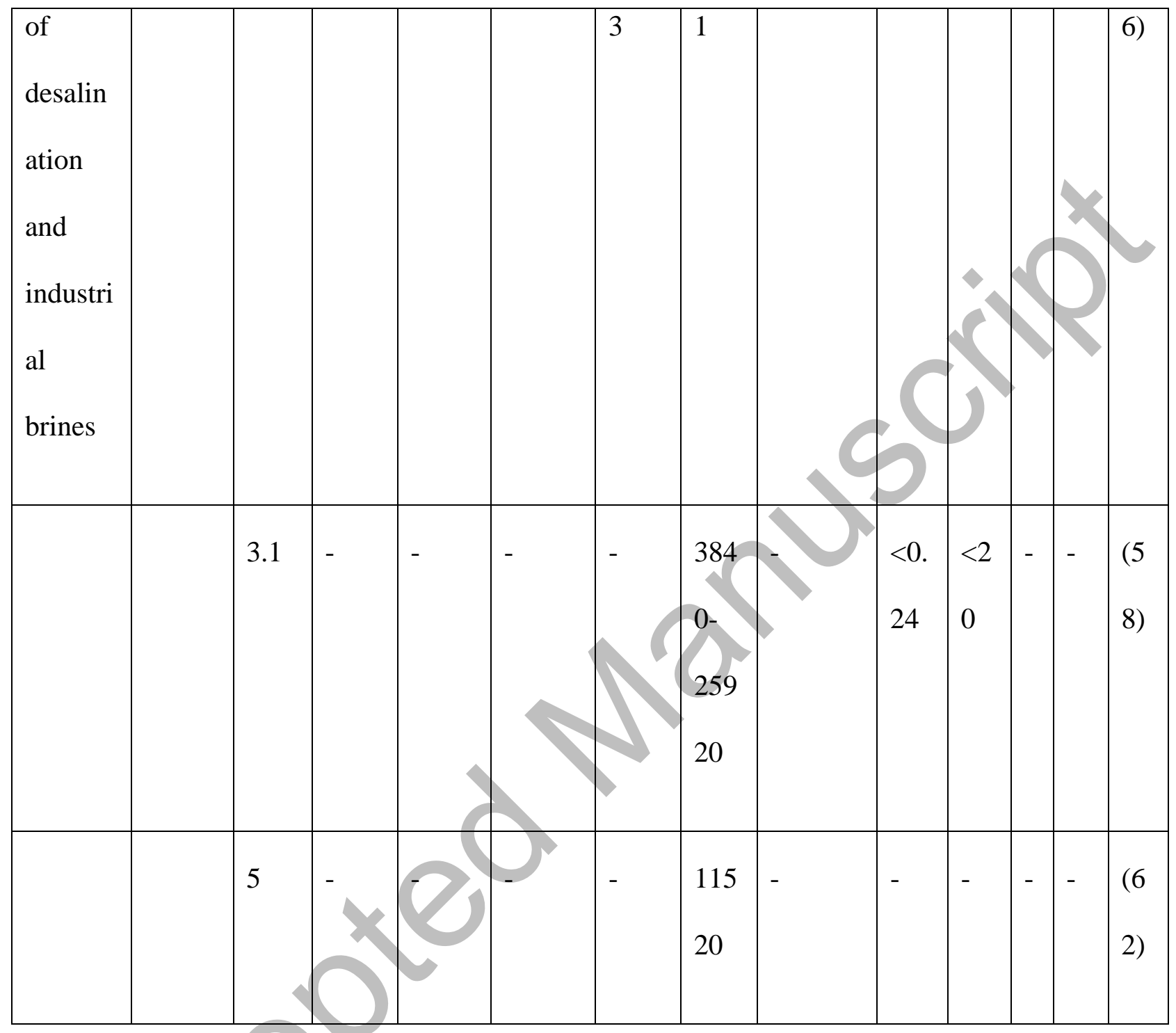

*Concentration in $\% \mathrm{w}^{*} \mathrm{w}^{-1}$. 
Table 3. Maximum concentration of impurities allowed in different commercial grades of $\mathrm{NaOH}$ compared to self-supply by EDBM. If not specified, concentration of impurities in $\% \mathrm{w}^{\cdot} \mathrm{w}^{-1}$.

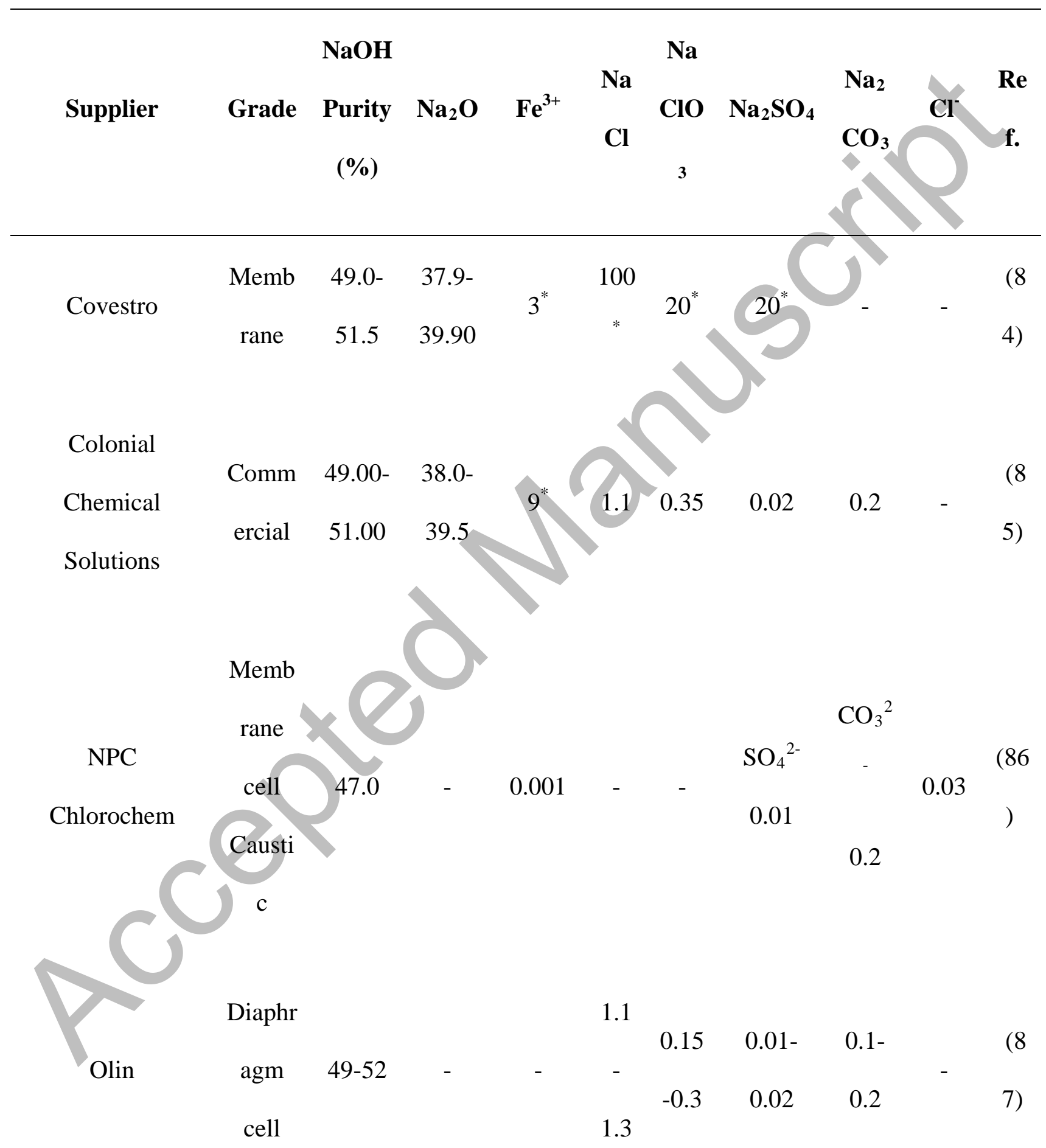




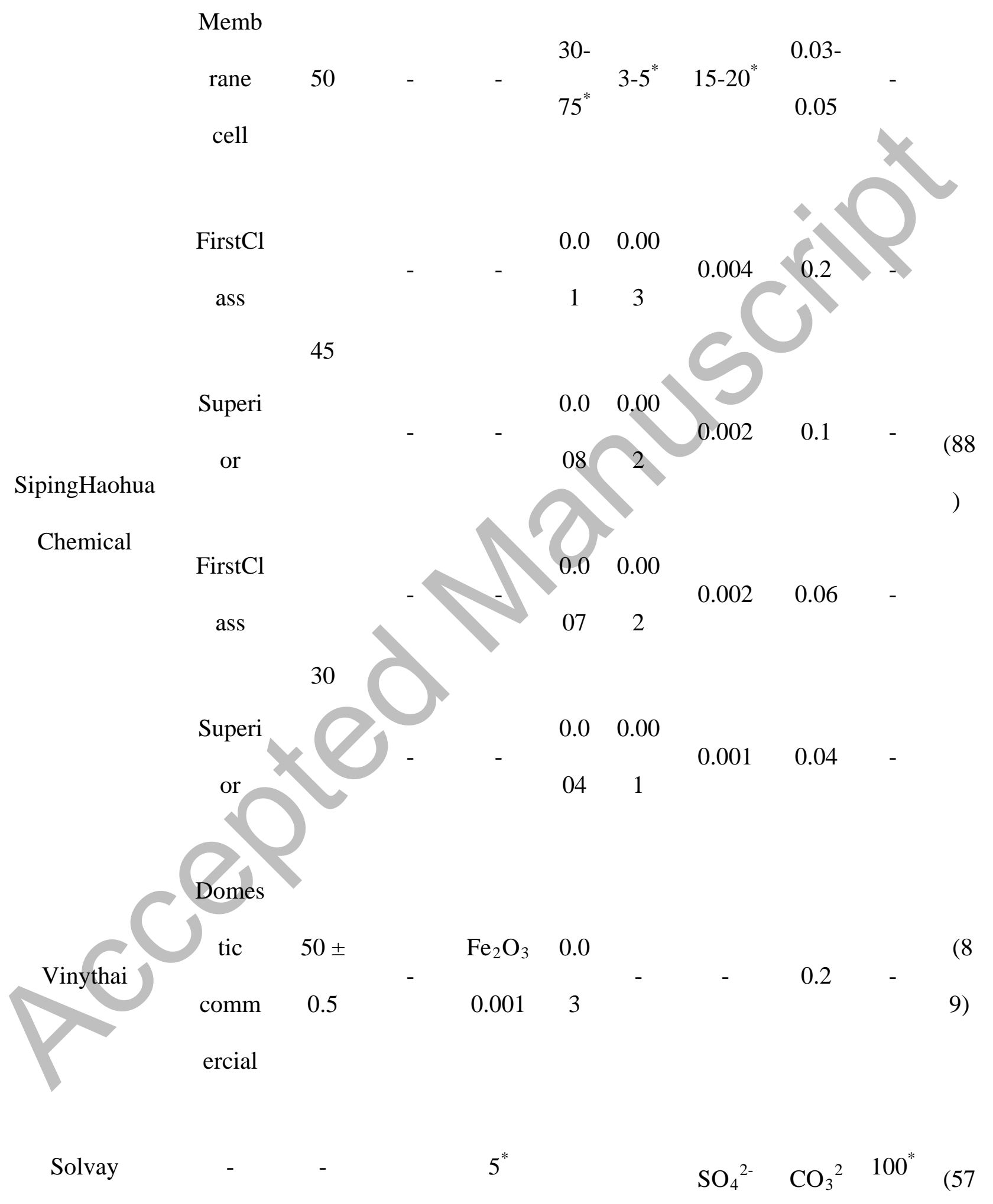




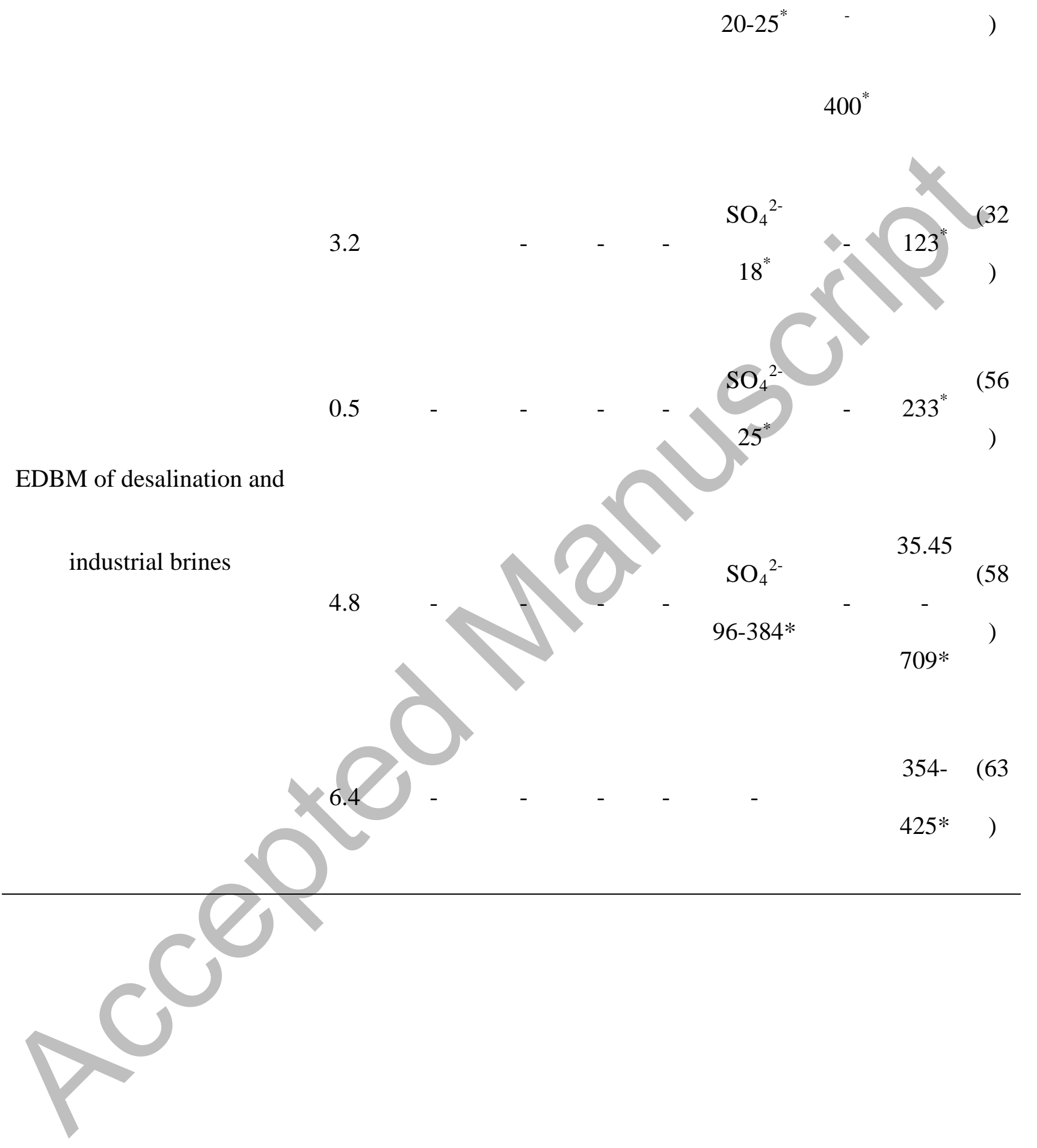

